Canadian Journal of Fisheries and Aquatic Sciences

Canadian

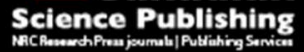

Journal canadien des sciences halieutiques et aquatiques

\title{
Brook trout use of thermal refugia and foraging habitat influenced by brown trout
}

\begin{tabular}{|r|l|}
\hline Journal: & Canadian Journal of Fisheries and Aquatic Sciences \\
\hline Manuscript ID & cjfas-2016-0255.R1 \\
\hline Manuscript Type: & Article \\
\hline Complete List of Authors: & $\begin{array}{l}\text { Hitt, Nathaniel; U.S. Geological Survey } \\
\text { Snook, Erin; U.S. Geological Survey } \\
\text { Massie, Danielle; U.S. Geological Survey }\end{array}$ \\
\hline Keyword: & $\begin{array}{l}\text { brook trout, brown trout, interference competition, thermal refugia, } \\
\text { GROUNDWATER < General }\end{array}$ \\
\hline \multicolumn{2}{|c}{} \\
\hline
\end{tabular}


1 Brook trout use of thermal refugia and foraging habitat influenced by brown trout

2

3 Nathaniel P. Hitt ${ }^{1}$

4 Erin L. Snook ${ }^{2}$

$5 \quad$ Danielle L. Massie ${ }^{3}$

6

7 U.S. Geological Survey, Leetown Science Center

811649 Leetown Road

9 Kearneysville, West Virginia 25430 USA

10

$11{ }^{1}$ Corresponding author: nhitt@usgs.gov, phone: 304-724-4463, fax: 304-724-4465

12 2esnook@usgs.gov

$13{ }^{3}$ DanielleLMassie@gmail.com 


\section{Abstract}

The distribution of native brook trout (Salvelinus fontinalis) in eastern North America is

16 often limited by temperature and introduced brown trout (Salmo trutta), the relative importance

17 of which is poorly understood but critical for conservation and restoration planning. We

18 evaluated effects of brown trout on brook trout behavior and habitat use in experimental streams

19 across increasing temperatures $\left(14-23^{\circ} \mathrm{C}\right)$ with simulated groundwater upwelling zones

20 providing thermal refugia $\left(6-9^{\circ} \mathrm{C}\right.$ below ambient temperatures). Allopatric and sympatric trout

21 populations increased their use of upwelling zones as ambient temperatures increased,

22 demonstrating the importance of groundwater as thermal refugia in warming streams. Allopatric

23 brook trout showed greater movement rates and more even spatial distributions within streams

24 than sympatric brook trout, suggesting interference competition by brown trout for access to

25 forage habitats located outside thermal refugia. Our results indicate that removal of introduced

26 brown trout may facilitate native brook trout expansion and population viability in downstream

27 reaches depending in part on the spatial configuration of groundwater upwelling zones.

29 Keywords: interference competition, thermal refugia, groundwater, experimental streams, brook

30 trout, brown trout 


\section{Introduction}

Interspecific competition is often influenced by abiotic factors (i.e., condition-specific competition, Dunson and Travis 1991). An understanding of condition-specific competition therefore is necessary to anticipate how changing environmental conditions will affect population dynamics and community composition (Tylianakis et al. 2008; Van der Putten et al. 2010). Anticipated increases in stream temperature (Snyder et al. 2015; Isaak et al. 2016) highlight a specific need to understand the relative importance and potential interactions of biotic and abiotic mechanisms of freshwater community assembly (Rahel et al. 2008; Wenger et al. 2011). Such knowledge can improve conservation strategies by focusing management actions on the biotic or abiotic conditions that regulate community assembly (Economo 2011).

Freshwater fishes provide an important model in this regard because (1) conditionspecific competition has been demonstrated across many taxonomic groups (cyprinidae, cottidae, Baltz et al. 1982; salmonidae, Taniguchi and Nakano 2000; fundulidae, cyprinodontidae, Carmona-Catot et al. 2013); (2) the longitudinal addition and replacement of stream fish species is influenced by interactive biotic and abiotic effects (Taniguchi and Nakano 2000; Hitt and Roberts 2012); and (3) introduced fishes have displaced native fish in many cases (Kreuger and May 1991; Cucherousset and Olden 2011). However, mechanistic predictions in this regard are limited in part due to confounded biotic and abiotic effects in observational field studies (see Hearn 1987) and experimental design limitations (see Fausch 1988, 1998; Weber and Fausch 2003). Here, we evaluate the relative importance of temperature and brown trout (Salmo trutta) on the distribution and behavior of brook trout (Salvelinus fontinalis) in an experimental stream system using a fully-crossed and replicated design. 
The distribution of native brook trout extends from the southern Appalachian mountains

54 (Georgia, USA) to the eastern Canadian Shield (Quebec, Canada) (MacCrimmon and Campbell

55 1969). In the southern portion of their range, brook trout are largely restricted to high-elevation

56 streams in forested catchments (Flebbe 1994; Hudy et al. 2008) that support cooler temperatures

57 (e.g., 7-day maximum of daily-mean temperatures $<23.3^{\circ} \mathrm{C}$, Wehrly et al. 2007). Physiological

58 responses to heat stress have been observed where stream temperatures exceed $21{ }^{\circ} \mathrm{C}$, and 23.4

$59{ }^{\circ} \mathrm{C}$ has been shown to be the upper limit for brook trout growth (Chadwick et al. 2015). Brook

60 trout utilize groundwater upwelling zones for spawning (Curry and Noakes 1995) as well as for

61 overwintering habitat (Cunjak and Power 1986) and thermal refugia during summer months

62 (Biro 1998; Baird and Krueger 2003; Petty et al. 2012). Observed patterns of brook trout

63 metapopulation structure and population isolation in stream networks (Aunins et al. 2015) may

64 be explained in part by landscape-scale movements to access thermal refugia and spawning

65 habitat (Petty et al. 2012; Kanno et al. 2014a). Thermal refugia from groundwater upwelling

66 zones can buffer stream fish populations from effects of land-use (Steffy et al. 2004; Stranko et

67 al. 2008). However, groundwater upwelling zones are spatially patchy within streams (Kanno et

68 al. 2014b; Dugdale et al. 2015; Snyder et al. 2015), and stream thermal responses to climate

69 change will depend in part on the spatial configuration and depth of groundwater upwelling

70 zones (Meisner et al. 1998; Kurylyk et al. 2014a; Snyder et al. 2015).

The downstream distribution limits for native brook trout are often associated with the

72 presence of introduced rainbow trout (Oncorhynchus mykiss) or brown trout (Salmo trutta)

73 (Vincent and Miller 1969; Gard and Flittner 1974; Kozel and Hubert 1989; Rahel and Hubert

74 1991; Petty et al. 2012). Introduced rainbow trout and brown trout have been linked to declines

75 in native brook trout abundance and occurrence based on time-series analysis (Moore et al. 1983; 
Larson and Moore 1985; Waters 1983, 1999), in-situ experiments (Fausch and White 1981;

Magoulick and Wilzbach 1998; Hoxmeier and Dieterman 2016), and statistical modeling inferences (McKenna et al. 2013; Wagner et al. 2013). The persistence of sympatric brook trout and introduced trout populations in some locations may be explained by abiotic factors related to stream size (Sheldon 1968; Fausch 1989) or seasonal hydrological variation (Larson et al. 1995; Strange and Habera 1998), suggesting condition-specific competitive effects.

Various mechanisms may account for the observed displacement of native brook trout by introduced brown trout. Brown trout have higher thermal tolerances than brook trout (Eaton et al. 1995, $c f$. Lee and Rinne 1980), and therefore warming temperatures may restrict brook trout before brown trout through physiological mechanisms (Flebbe 1994; Fausch 1989; see also Chadwick et al. 2015). Introduced brown trout displace native brook trout for access to flow refugia (i.e., resting positions) (Fausch and White 1981), and this may decrease brook trout growth by increasing respiration relative to consumption (see Hartman and Cox 2008). This hypothesis is supported by the observed decrease of brook trout growth in the presence of brown trout (Carlson et al. 2007; Hoxmeier and Dieterman 2013, cf. Öhlund et al. 2008). In addition, redd superimposition or hybridization by brown trout may reduce brook trout abundance and population growth (Sorensen et al. 1995; Essington et al. 1998; Cucherousset et al. 2008), and predation of juvenile brook trout by adult brown trout may account for brook trout population declines (Alexander 1977). Alternatively, observed declines may be because brook trout are more susceptible to harvest by anglers than brown trout when occurring in sympatry (Cooper 1952; Marshall and MacCrimmon 1970).

Prior research yields inconsistent conclusions regarding the importance of interspecific competition between brook trout and brown trout as well as the potentially mediating role of 
temperature. Experimental stream studies have concluded that brook trout competitively dominate brown trout of equal size (Fausch and White 1986) as well as the converse (DeWald and Wilzbach 1992). Differences between these studies cannot be attributed to stream temperatures (constant $14-15^{\circ} \mathrm{C}$ in both cases) but may be due to effects of habitat cover (present in DeWald and Wilzbach (1992) versus absent in Fausch and White (1986)). Nonetheless, observed effects of brown trout on brook trout microhabitat use from DeWald and Wilzbach's (1992) laboratory study are consistent with results of in-situ research based on experimental removals of brown trout (Fausch and White 1981). Taniguchi et al. (1998) concluded that brook trout and brown trout were competitively equivalent at temperatures $\leq 20^{\circ} \mathrm{C}$, above which both species became subordinate to creek chub (Semotilus atromaculatus). In contrast, brown trout have been shown to increase their competitive advantage over other salmonid species as temperatures increase from 10 to $20^{\circ} \mathrm{C}$ (Colorado River cutthroat trout Oncorhynchus clarki pleuritcus, DeStaso and Rahel 1994) and from 14 to $17^{\circ} \mathrm{C}$ (Arctic char Salvelinus alpinus, Jonsson 2009).

Prior experimental research on this topic is limited by spatially homogenous thermal treatments (i.e., uniform heating of tanks), and thus cannot account for thermal habitat patchiness due to groundwater upwelling (Brunke and Gonser 1997; Torgerson et al. 1999; Ebersole et al. 2003; Kanno et al. 2014b; Snyder et al. 2015). Moreover, heterogeneity in resource availability is an important design consideration in testing for interspecific competition (Connell 1983, Weber and Fausch 2003). In this study we compared brook trout in the presence and absence of brown trout with spatially- structured resources defined by thermal refugia and foraging locations. We created thermal refugia by simulating groundwater upwelling through substrates across increasing ambient temperatures $\left(14,17,20,23{ }^{\circ} \mathrm{C}\right)$, and we introduced food from belt feeders 
122 located outside thermal refugia to create spatial structure in foraging habitat quality. This

123 temperature range is useful because it includes approximate temperatures for optimal brook trout

124 growth $\left(13{ }^{\circ} \mathrm{C}\right.$, Baldwin 1957) as well as upper limits to positive growth $\left(23^{\circ} \mathrm{C}\right.$, Chadwick et al.

125 2015). We hypothesized that both species would increase their use of upwelling zones as

126 ambient temperatures increased, and that competitive advantage would shift from brook trout to

127 brown trout with increasing temperatures.

\section{Methods}

We applied experimental treatments to a set of indoor artificial streams located at the consists of connected fiberglass tanks providing pool and riffle habitat as described by Matthews et al. (2006). Streams extend for $7.6 \mathrm{~m}$, each encompassing a surface area of $6.9 \mathrm{~m}^{2}$ and volume of $3.8 \mathrm{~m}^{3}$. A 1-horsepower pump supplied a recirculating flow rate of $0.11 \mathrm{~m}^{3} /$ minute. Target temperatures were set through a combination of heating (Aqua Logic $12 \mathrm{~kW}$ in-line heater) and cooling (Aqua Logic $17.4 \mathrm{~kW}$ chiller barrel) (Fig. 1). The bottom of each tank was covered with coarse gravel ( $25 \mathrm{~mm}$ diameter), and natural lighting was supplemented with overhead lighting allopatric treatments but shared water through a combined sump and filtration system (Fig. 1). operated by the West Virginia Department of Natural Resources. All fish were adults (mean

143 length $=345 \mathrm{~mm} \mathrm{TL}$, mean weight $=622 \mathrm{~g}$ ), and mean weights and lengths were not

144 significantly different between species ( $p>0.2$ and $p>0.9$, respectively; Appendix A). Although 
145 brown trout are often larger than brook trout where sympatric in streams (e.g., Fausch and White 146 1986), the equivalence of body size between species was appropriate in our study because body 147 size usually predicts dominance in salmonids (Fausch and White 1986; Fausch 1988). Fish were 148 acclimated to $14{ }^{\circ} \mathrm{C}$ for 7 days prior to experimental trials. Fish were fed $5 \mathrm{~mm}$ floating pellets at 149 a rate of $\sim 1 \%$ total biomass/day (Finfish G pellets, Zeigler Brothers, Inc.) from 12-hour belt 150 feeders in fixed locations (Fig. 1).

We evaluated effects of brown trout on brook trout behavior and habitat selection using a

152 substitutive design by attempting to hold total fish density constant between sympatric and 153 allopatric treatments. This approach is appropriate for assessing the effects of species known to 154 compete in natural systems (Fausch 1998), and prior studies have used this method to assess 155 effects of competition between native and non-native fishes (Taniguchi and Nakano 2000; 156 McMahon et al. 2007). For each stream we assembled experimental populations from 10 157 individuals for a total linear density of $1.3 \mathrm{fish} / \mathrm{m}(10$ brook trout or 5 brook trout and 5 brown 158 trout), a level within the range of observed densities for stream-dwelling brook trout (Kanno et 159 al. 2015). Saprolegnia infection caused 2 brook trout mortalities and reduced allopatric treatment 160 densities to 8 fish (replicates 2-6), but sympatric treatments were held at a uniform density across 161 all replicates. Individual brook trout were randomly reassigned to allopatric and sympatric 162 populations among 6 replicated trials, and allopatric and sympatric treatments were randomly 163 assigned to streams across replicates. Within each trial, thermal treatments regulated ambient water temperatures at 14, 17, 20, 165 and $23{ }^{\circ} \mathrm{C}$ for allopatric and sympatric populations. This temperature range was selected to 166 include upper levels stressful for brook trout physiological function $\left(20-21{ }^{\circ} \mathrm{C}\right.$, Hartman and Cox 167 2008; Chadwick et al. 2015) without reaching upper incipient lethal levels for brook trout (25-30 
168 169

170

171

172

173

174

175

176

177

178

179

180

181

182

183

184

185

186

187

188

189

190

${ }^{\circ} \mathrm{C}$, Fry et al. 1946; Lee and Rinne 1980). This temperature range also encompasses observed summer temperatures of native brook trout habitat in Virginia (Snyder et al. 2015). Ambient

temperatures were held constant during daylight hours and were increased overnight by $\sim 1$

${ }^{\circ} \mathrm{C} /$ hour, and similar rates have been observed in natural streams (Constantz et al. 1994).

To create spatial structure in thermal habitat, we simulated groundwater upwelling by introducing spring water $\left(\sim 14^{\circ} \mathrm{C}\right)$ into substrates in downstream pools (Fig. 1; Appendix B). Groundwater was run through flexible tubing $(1.3 \mathrm{~cm}$ diameter $)$ and into a $30 \mathrm{~cm}$ square PVC manifold (1.3 cm diameter) that was perforated to allow water flow. Groundwater flow rate was set to $3 \mathrm{~L} /$ minute with flow-regulation disks. Temperature loggers (Onset ProV2) were deployed in an upstream pool to measure ambient temperatures and in a downstream pool near the substrate surface to measure incoming groundwater temperatures at hourly increments. Conductivity, dissolved oxygen, and $\mathrm{pH}$ were sampled repeatedly at $14{ }^{\circ} \mathrm{C}$ and $23{ }^{\circ} \mathrm{C}$ to encompass the range of experimental temperatures (Table 1).

We conducted daily visual observations to index brook trout spatial distribution within streams and evenness across connected tanks (i.e., pool and riffle mesohabitat units). We recorded number of fish and their species identity within pool and riffle tanks at least 3-times per day, including morning and afternoon samples. Of the 24 experimental days, $22(92 \%)$ supported 5 or more visual samples per day (mean $=6.8$ samples/day). To minimize disturbances to fish, observations were made through plexiglass windows located on the side of pool tanks (see Matthews et al. 2006) that were covered with black plastic when not in use. We quantified distributional evenness within streams using a variant of Simpson's index $(E)$ (Equation 1, Simpson 1949): 
$191 \quad(1) \quad E=\frac{1 / \sum p_{i}^{2}}{s}$

where $p_{i}$ is the proportion of brook trout or brown trout in tank $i$ across $s=5$ tanks per stream (3 pools and 2 riffles). Payne et al. (2005) recommended this index for quantifying spatial evenness in organismal distributions, and it has been previously applied for this purpose in fish ecology research (e.g., Didrikas and Hansson 2008).

To assess brook trout movement rates, aggressive behaviors, and opercular ventilation rates, we collected underwater video data using a GoPro HERO3 Black Edition (1440 pixels, 48 frames/second). We mounted the waterproof camera case to a plastic board $(5 \mathrm{~cm} \mathrm{x} 50 \mathrm{~cm})$ to stabilize the camera and allow repeated observations from the same perspective. Each day of the experiment we collected 11 minutes of video from each stream and discarded the first minute to avoid disturbance associated with the placement of the camera (see Biro 1998). Video samples were collected from pools with the highest density of fish during the sampling period. Upstream and downstream pools (see Fig. 1) were sampled equivalently at temperature levels between 14 and $20^{\circ} \mathrm{C}$, but downstream pools were sampled in 10 out of 12 cases $(83 \%)$ when ambient temperatures reached $23{ }^{\circ} \mathrm{C}$ and fish preferentially utilized thermal refugia (see Results). Video samples were collected between noon and 3:30 pm daily, and the majority of samples (81\%) were collected between noon and $2 \mathrm{pm}$. We quantified movement rate by species as the number 209 of times a fish moved in or out of the observation tank during the 10-minute video sample. We 210 did not attempt to record individual-level movement patterns. Aggression was quantified from daily video samples as the sum of nips, charges, and

212 chases following Keenleyside and Yamamoto (1962) and Hartman (1963). Ventilation rate was 213 quantified as the beating rate of opercula for brook trout from daily video samples to provide an 
214 index of oxygen consumption, resting metabolic rate, and stress responses (Cairns et al. 1982;

215 Millidine et al. 2008). For each video sample, we measured the time for 30 operulum beats in 216 seconds $(b)$ and calculated ventilation rate per minute as $3600 / 2 b$. We sampled ventilation rates

217 for 5 randomly-selected brook trout and averaged values across individuals within each video 218 sample. Similar methods have been used to assess ventilation rates in salmonid fishes (Walker et 219 al. 1988).

Temperature and brown trout treatments were applied to a fully-crossed design across 6

221 replicated trials. We fit linear mixed models to evaluate the effect of brown trout presence (fixed

222 effect) on brook trout spatial distribution and evenness, movement, aggression, and ventilation

223 while accounting for temperature $\left(14,17,20,23^{\circ} \mathrm{C}\right)$ as random effects. The inclusion of random

224 effects in this context minimizes potential effect of pseudoreplication on statistical inference

225 (Bolker et al. 2009) in our thermal treatment design. We used restricted maximum likelihood 226 procedures to fit mixed-models using library lme4 in R (Bates et al. 2015). We applied $z$-score 227 transformations to standardize response variables and calculated marginal $R^{2}$ (fixed-effects only) 228 and conditional $R^{2}$ (fixed and random effects) to summarize model performance (Vonesh et al. 229 1996; Nakagawa and Schielzeth 2013). We assessed the significance of standardized coefficients 230 from 95\% confidence intervals calculated from 1000 bootstrapped models with random sampling 231 of the data. Stream identity (1-2) and replicate number (1-6) had insignificant effects on brook 232 trout responses (i.e., standardized model coefficient 95\% CIs included 0) and therefore were 233 excluded from further consideration. 
Observed ambient temperatures closely approximated target levels: 95\% of all hourly

237

238

239

240

241

242

243

244

245

246

247

248

249

250

251

252

253

254

255

256

257

258

temperature measurements were within $0.7^{\circ} \mathrm{C}$ of the target temperatures (Fig. 2). Temperatures

near upwelling zones ranged from $\sim 14-19^{\circ} \mathrm{C}$ and created thermal refugia $6-9{ }^{\circ} \mathrm{C}$ below ambient temperatures (Fig. 2). Upwelling temperatures were several degrees warmer in the last three replicates than the first three but were below ambient temperatures of $17-23^{\circ} \mathrm{C}$ in all replicates

(Fig. 2). Water quality was typical of calcium-rich springs that service the Leetown Science Center (Kozar et al. 2007) as characterized by alkaline pH and high conductivity. Specific conductance and $\mathrm{pH}$ increased with temperature (Table 1), likely due to increased calcium dissolution and associated ionic loading.

Allopatric brook trout exhibited different patterns of upwelling habitat use, spatial evenness, and movement than brook trout in the presence of brown trout. The percent of fish occupying upwelling habitat zones (see Fig. 1) increased with temperature for allopatric brook trout as well as sympatric brook trout and brown trout (Fig. 3a), indicating the importance of groundwater upwelling as thermal refugia for both species. However, sympatric brook trout exhibited greater use of the upwelling habitat than allopatric brook trout at all temperatures. For instance, over half of the sympatric brook trout were located in the upwelling zone at all temperatures, whereas allopatric brook trout reached this level of upwelling use at $23{ }^{\circ} \mathrm{C}$ (Fig. 3a). Mixed-model results indicated monotonic increases in brook trout use of upwelling habitat with increasing temperatures (Fig. 3b). The standardized effect of brown trout presence on brook trout upwelling use was approximately twice that of the highest temperature level (Fig. 3b). Marginal and conditional $R^{2}$ values indicated that the relative importance of brown trout was greater than the relative importance of temperature on brook trout upwelling habitat use $(0.643$ and 0.357 , respectively; Table 2). 
Spatial evenness of brook trout within streams decreased in the presence of brown trout,

260 whereas temperature had insignificant effects. Allopatric brook trout were more evenly

261 distributed than sympatric brook trout at all temperature levels, and allopatric brook trout were

262 more similar to sympatric brown trout than sympatric brook trout in this regard (Fig. 4a). Brown

263 trout reduced brook trout spatial evenness within streams (i.e., 95\% CI $<0$ ), but temperature

264 levels had no effect in this regard (i.e., 95\% CIs include 0) (Fig. 4b). Likewise, the effect of

265 brown trout accounted for $99 \%$ of the conditional $R^{2}$ for the model of brook trout spatial

266 evenness (Table 2).

267 Inter-tank movement rates of brook trout decreased in the presence of brown trout.

268 Allopatric brook trout showed greater movement rates than sympatric brook trout or sympatric

269 brown trout at all temperature levels (Fig. 5a). This result could not be attributed to differences

270 in brook trout density (i.e., twice the number of brook trout in allopatric vs. sympatric

271 treatments) because the difference in observed movement rates was more than twice as high in

272 the allopatric vs. sympatric populations (Fig. 5a). Moreover, the movement rates for allopatric

273 brook trout were generally greater than for the total movement observed for all fish in the

274 sympatric treatments (i.e., brown trout and brook trout combined) (Fig. 5a). Although fish

275 moved into thermal refugia as ambient temperatures increased (Fig. 3), temperature was

276 unrelated to brook trout movement from video samples (i.e., 95\% CIs include 0) whereas brown

277 trout showed a significant negative effect in this regard (Fig. $5 b$ ). The conditional $R^{2}$ of the brook

278 trout movement model was 0.377 , of which $98 \%$ was attributable to the effect of brown trout

279 (Table 2).

Observed brook trout aggression was not influenced by temperature or brown trout. The

281 linear mixed-model for brook trout aggression supported a low conditional $R^{2}(0.09)$, and 
282 therefore much of the observed variation was not accounted for by thermal or biotic treatments

283 (Table 2). Brown trout aggression generally increased with temperature (Fig. 6a), but the effect

284 of brown trout on brook trout aggression rates was insignificant (Fig. 6b). Moreover, the relative

285 importance of temperature exceeded the importance of brown trout in partitioning the conditional

$286 R^{2}$ for the model of brook trout aggression (Table 2).

287 Brook trout ventilation rates were influenced by temperature but not the presence of

288 brown trout. Ventilation rates increased monotonically across temperature levels from $\sim 55$

289 beats/minute at $14{ }^{\circ} \mathrm{C}$ to $\sim 80$ beats/minute at $23{ }^{\circ} \mathrm{C}$ (Fig. $7 a$ ). The effect of brown trout on brook

290 trout ventilation was insignificant as indicated by $95 \%$ CIs (Fig. $7 b$ ). In contrast, temperature

291 levels showed monotonically increasing effects on brook trout ventilation rate (Fig. 7b), and

292 temperature was the only significant predictor in the model, given that $<0.01 \%$ of the conditional

$293 R^{2}(0.763)$ was accounted for by the effect of brown trout (i.e., marginal $R^{2}$ ) (Table 2 ).

294 Effects of brown trout were also evident in the correlation structure of brook trout

295 responses. Upwelling habitat use was negatively associated with movement rates for both

296 allopatric and sympatric brook trout (Spearman $r>|0.43|, p<0.01$, respectively), but only

297 sympatric brook trout exhibited a significant correlation between spatial evenness and upwelling

298 habitat use (Table 3). Upwelling habitat use was positively correlated with brook trout

299 ventilation rates in the absence but not presence of brown trout (Table 3). Brook trout ventilation

300 rates also were positively correlated with aggressive behaviors for allopatric and sympatric brook

301 trout, but only in the presence of brown trout was brook trout aggression significantly correlated

302 with movement rates (Table 3$)$. Only 4 of the 10 significant $(p<0.05)$ correlations in brook trout

303 response variables were shared between allopatric and sympatric treatments (Table 3). 


\section{Discussion}

Our results indicate that brown trout affect brook trout behavioral thermoregulation and access to foraging habitats. This study expanded on prior research by regulating the spatial structure of thermal refugia and foraging resources across increasing temperatures. We used experimental streams with a fully-crossed experimental design to partition the relative importance of biotic and abiotic conditions for brook trout while accounting for variation across replicates and spatial positions of streams within the laboratory. Although observed interspecific interactions were not strictly temperature-dependent, brown trout restricted brook trout distributions and limited their access to foraging habitats outside thermal refugia. Our study underscores the importance of resource spatial configuration in streams (Dunning et al. 1992; Schlosser 1991), and our results have implications for native brook trout conservation in the context of climate change and non-native species management.

Both species increased their use of groundwater upwelling zones with increasing temperatures (Fig. 3a) as expected. However, we did not find evidence for our prediction that competitive advantage would shift from brook trout to brown trout with increasing temperatures. Instead, brown trout restricted brook trout distribution and spatial evenness within streams at all temperature levels evaluated (Fig. $4 b$ ) suggesting interference competition for access to belt feeders located outside thermal refugia (see Fig. 1). Consistent with our results, field studies have shown that brown trout exhibit faster growth rates than sympatric brook trout (Carlson et al. 2007; Hoxmeier and Dieterman 2013), and experimental removals of brown trout have yielded increased brook trout growth rates and biomass (Hoxmeier and Dieterman 2016). Although our results indicate that brown trout displace brook trout from foraging resources across a large range of temperatures $\left(14-23{ }^{\circ} \mathrm{C}\right)$, we would expect the energetic effects of brown trout to increase 
328

329

with water temperature (see Carlson et al. 2007) because both species exhibit density-dependent growth during summer months (Jenkins et al. 1999; Utz and Hartman 2009) and brook trout metabolic efficiency decreases rapidly as temperatures exceed $20^{\circ} \mathrm{C}$ (Hartman and Cox 2008). Given the similarity of ambient and groundwater temperatures at $14^{\circ} \mathrm{C}$ (Fig. 2), we interpret the prevalence of sympatric brook trout in the upwelling habitat at this temperature level as displacement from upstream foraging habitat rather than selection for groundwater habitat. Additional research is needed to test this interpretation by manipulating the spatial location of foraging resources relative to groundwater upwelling locations.

Our results differ from prior research showing competitive equivalency of these species across temperature levels (Taniguchi et al. 1998) and showing brook trout out-competing brown trout at relatively low temperatures $\left(14^{\circ} \mathrm{C}\right.$, Fausch and White 1986). However, our results are consistent with prior research showing brown trout dominance over brook trout in experimental settings (DeWald and Wilzbach 1992) and field studies (Öhlund et al. 2008). Differences with prior studies may be explained by effects of fish size, source stock, or spatial structure of limiting resources. We evaluated large adult fish (310-380 mm total length, Appendix A), whereas Fausch and White (1986) evaluated juvenile trout and Taniguchi et al. (1998) evaluated smaller trout (107-165 mm fork length) than our study. Field studies have revealed stronger interspecific competition between adult brook trout and brown trout than juveniles (Fausch and White 1981; Hoxmeier and Dieterman 2013; $c f$. Hutchinson and Iwata 1997), and this may explain why we observed competitive effects that other studies did not. However, this is probably not a complete explanation because at least one study showing brown trout dominance over brook trout evaluated fish of similar size as in Taniguichi et al. (1998) (mean TL $=107 \mathrm{~mm}$, DeWald and Wilzbach 1992). Our results probably represent conservative estimates of brown trout effects in 
351 natural ecosystems because brown trout tend to be larger than brook trout when occurring in 352 sympatry (Fausch and White 1981; Carlson et al. 2007).

Alternatively, differences among studies may be due to effects of hatchery propagation.

354 Experimental trials have shown hatchery-sourced brook trout to be more aggressive than brook trout collected from wild populations (Moyle 1969) as known from other salmonid species (e.g.,

356 cutthroat trout Oncorhynchus clarki, Mesa 1991). Hatchery-sourced brook trout also have

357 exhibited less use of cover and greater movement rates than wild brook trout (Vincent 1960), and

358 brown trout show similar patterns (Bachman 1984). In the present study we used hatchery-

359 sourced fish and found stronger effects of interspecific competition than shown from laboratory-

360 based studies of wild brook trout and brown trout (Fausch and White 1986; Taniguchi et al.

361 1998). It therefore is possible that genetic or behavioral effects associated with hatchery

362 propagation influenced our results. However, our observations were consistent with DeWald and

363 Wilzbach's (1992) study of wild brook trout and hatchery-sourced brown trout, indicating that

364 our results are unlikely to be solely due to source population effects. We recommend in-situ

365 experimental removals of brown trout from sympatric brook trout populations following Fausch

366 and White (1981) across a gradient of stream temperatures and thermal refugia configurations to

367 evaluate our results within natural settings.

368 Our study demonstrated the importance of thermal refugia for trout. We observed that 369 trout aggregated into thermal refugia when ambient temperatures exceed $20^{\circ} \mathrm{C}$ (i.e., $>50 \%$ 370 abundance; Fig. 3a). Baird and Krueger (2003) also identified a behavioral response of brook 371 trout where stream temperatures exceeded $20^{\circ} \mathrm{C}$ such that observed body temperatures were on 372 average $4{ }^{\circ} \mathrm{C}$ cooler than ambient temperatures, indicating fish movements to access thermal 373 refugia. Field studies have also demonstrated brook trout movements to access thermal refugia 
374 within stream networks (Petty et al. 2012) and lake ecosystems (Curry and Noakes 1995; Biro

375 1998) as known for other salmonid species (Chinook salmon Oncorhynchus tshawytscha,

376 Torgerson et al. 1999; rainbow trout, Ebersole et al. 2001; lake trout Salvelinus namaycush,

377 Snucins and Gunn 1995). Moreover, the absence of groundwater inputs and thermal refugia has

378 been attributed to delays in brook trout spawning during years with above-average air

379 temperatures (Warren et al. 2012) whereas such phenological effects would not be expected in

380 groundwater-dominated locations (e.g., Biro 1998). Brook trout aggregation into upwelling areas

381 was associated with lower movement rates for allopatric and sympatric populations (Table 3) as

382 expected. In contrast, use of upwelling zones was associated with decreased spatial evenness

383 only for sympatric brook trout (Table 3), indicating the capacity for brook trout use of forage

384 habitats in high temperatures $\left(>20^{\circ} \mathrm{C}\right)$ if brown trout are absent.

385

The spatial structure of groundwater exchange processes in streams is expected to

386 regulate the utility of thermal refugia for fishes (Poole et al. 2006). Hyporheic exchange at the

387 microhabitat scale (i.e., $10^{-1}-10^{0} \mathrm{~m}$ scale, Harvey and Bencala 1993) is nested within

388 groundwater discharge dynamics at the reach-scale (i.e., $10^{1}-10^{2} \mathrm{~m}$ scale, Dugdale et al. 2015;

389 Snyder et al. 2015), and both scales may structure thermal habitat for fishes (Frissell et al. 1986;

390 Fausch et al. 2002; Poole et al. 2006). Our study evaluated thermal refugia $6-9^{\circ} \mathrm{C}$ below ambient

391 temperatures within a relatively small distance ( $7.6 \mathrm{~m}$-long streams), and this temperature

392 difference is larger than expected effects of hyporheic exchange at the meter-scale (Harvey and

393 Bencala 1993) but resembles potential thermal heterogeneity observed at the stream reach scale

394 (Dugdale et al. 2015; Snyder et al. 2015) and stream network scale (i.e., inter-stream effects,

395 Kaya et al. 1977; Benda et al. 2004; Dugdale et al. 2013). Our study therefore provides a 
396 perspective most applicable for stream reaches near downstream distribution limits of brook 397 trout.

Brown trout restricted brook trout movements and spatial distributions within streams,

399 but we did not observe effects of brown trout on brook trout aggression (Fig. 6b). Instead, brown trout were generally more aggressive than brook trout at all temperatures evaluated (Fig. 6a). We

401 observed multiple instances of brown trout charging and chasing brook trout near belt-feeder

402 locations (see Fig. 1), particularly when ambient temperatures exceeded $20^{\circ} \mathrm{C}$, but these

403 observations were not collected systematically for analysis. The relatively short observation

404 window in our study (10 minutes/day) may explain the absence of an effect, as suggested by the

405 relatively high among-sample variance observed for aggressive behaviors (Fig. 6a). By

406 comparison, Hutchinson and Iwata (1997) collected aggression data by sampling at 5-minute

407 increments hourly for multiple days and Dickson and MacCrimmon (1982) observed aggressive

408 interactions for 15 minutes/day. We would expect intraspecific competition to be more intense

409 than interspecific competition because conspecifics would exhibit greater niche-overlap (Connell

410 1983), particularly for brook trout which are known to exhibit greater intraspecific aggression

411 than other salmonid species (Hutchinson and Iwata 1997). Despite the expected importance of

412 intraspecific competition, we observed more aggression in sympatric populations than among

413 allopatric brook trout (Fig. 6a), suggesting interference competition by brown trout.

Ventilation rates increased monotonically with ambient temperature levels but were

415 invariant to the presence or absence of brown trout (Fig. 7b). This pattern indicates increased

416 oxygen consumption at higher temperatures, and such a temperature effect has been observed in

417 brook trout and brown trout (Job 1955; Beamish 1964). Observed brook trout ventilation rates

418 ranged from approximately 50-90 beats/minute (Fig. 7a) which was somewhat lower than 
419 observed for smaller brook trout at $11^{\circ} \mathrm{C}$ (approximately 95 beats/minute, Walker et al. 1988).

420 Although the magnitude of observed ventilation rate increases across temperatures is generally

421 consistent with previously reported increases over time in response to acid stress $(\mathrm{pH}=4.8$,

422 Walker et al. 1988), caution is warranted in interpreting ventilation rate as a stress response

423 because increased ventilation responses may not necessarily indicate the magnitude of the

424 stressor (Barreto and Volpato 2004). Nonetheless, observed ventilation rates sampled primarily

425 from the groundwater upwelling zone at $23{ }^{\circ} \mathrm{C}$ (see Fig. 1) did not provide a complete refuge

426 from physiological effects associated with ambient temperature exposure. This may be due to the

427 mixing of ambient and upwelling water in the groundwater upwelling zone. Dye tests indicated

428 that groundwater upwelling from substrates provided a discrete spatial zone of cold water

429 (Appendix B), but fish movement would increase mixing of water temperatures. This may also

430 explain the observed differences in upwelling-zone temperatures across experimental replicates

431 (Fig. 2).

An important limitation of our study is the lack of individual-level inferences. For

433 instance, we could not resolve the individual identities of allopatric brook trout that periodically

434 utilized high temperatures to access foraging habitat. Future research using passive integrated

435 transponder tags and fixed antennas is recommended to address this question. Moreover, our

436 design randomly re-assigned brook trout to allopatric and sympatric treatments across replicates,

437 and therefore we could not discern effects of brown trout on individual growth rates as an index

438 of foraging efficiency as previously demonstrated (Fausch and White 1986; Taniguchi et al.

439 1998; DeWald and Wilzbach 1992). We also cannot resolve potential social interactions that

440 structure dominance hierarchies within and between trout species (Newman 1956; White and

441 Gowan 2013). However, because we randomly assigned allopatric and sympatric treatments to 
442 streams across replicates, handling-effects were equally distributed among all individuals and 443 thus are not expected to introduce directional biases.

Our results provide direct evidence for interspecific competition between brook trout and

445 brown trout by use of a substitutive design whereby we attempted to hold total fish densities

446 constant. This approach is appropriate for investigating interspecific competition between

447 species known to compete in natural systems, and is more appropriate for this purpose than

448 additive designs which conflate total fish density with species composition (Fausch 1988, 1998;

449 Weber and Fausch 2003). Total fish densities in our study ranged from 1.3-1.5 fish/m, within the 450 observed range of brook trout densities in Appalachian streams (Kanno et al. 2015). However, 451 mortality of 2 brook trout reduced densities within the sympatric treatment after the first replicate 452 due to infection of Saprolegnia sp., an oomycete mold causing lethality through haemodilution 453 (Woo and Bruno 2011). DeWald and Wilzbach (1992) observed a similar pattern whereby brook 454 trout in the presence of brown trout succumbed to Saprolegnia infection whereas neither 455 allopatric brook trout nor brown trout were affected. They interpreted this effect as a stress 456 indicator in brook trout exposed to brown trout (DeWald and Wilzbach 1992), and our 457 observations are consistent with their hypothesis.

459 habitat, and our results suggest that removal of brown trout may facilitate this goal for brook 460 trout at their downstream limits. We showed that both species preferentially selected thermal 461 refugia when ambient temperatures exceeded $20{ }^{\circ} \mathrm{C}$, and that brown trout restricted brook trout 462 access to forage resources at such temperature levels. Anticipated increases in stream 463 temperatures (Snyder et al. 2015; Isaak et al. 2016) therefore will be important for brook trout 464 not only through direct physiological mechanisms (Chadwick et al. 2015) but also through 
465 indirect pathways associated with brown trout competition. Management for thermal refugia in 466 streams may be feasible in some cases (Kurylyk 2014b), but management for non-native trout

467 abundance has been shown to be feasible albeit energy intensive (Larson and Moore 1985).

468 Furthermore, downstream expansion of native brook trout could enhance fisheries management 469 by increasing brook trout growth in downstream locations. Limitations of this approach will 470 depend in part on the spatial configuration of thermal refugia at the stream reach scale and the 471 willingness of the angling community to conserve native fishes.

472

473 Acknowledgements

474 The authors thank C. Snyder, Z. Johnson, D. Smith, S. Faulkner, D. Weller, J. Mullican,

475 M. Morgan, J. Roach, S. Strecky, M. Hudy, S. Phillips, D. Spooner, and 2 anonymous reviewers 476 for assistance with this manuscript. Fish handling protocols were approved by USGS IACUC 477 review. Funding was provided by the US Geological Survey Chesapeake Bay Program. E. Snook 478 was supported by a USGS contract with IMSG. Any use of trade, product, or firm names does 479 not imply endorsement by the US government.

480

$481 \quad$ Literature cited

482 Alexander, G.R. 1977. Consumption of small trout by large predatory brown trout in the North 483 484 485 Araújo, M.B., and Luoto, M. 2007. The importance of biotic interactions for modeling species distributions under climate change. Glob. Ecol. Biogeog. 16: 743-753. doi:10.1111/j.1466-8238.2007.00359.x. 
488 489

490

491

492

493

494

495

496

497

498

499

500

501

502

503

504

505

506

507

508

509

Aunins, A.W., Petty, J.T., King, T.L., Schilz, M., and Mazik, P.M. 2015. River mainstem thermal regimes influence population structuring within an Appalachian brook trout population. Conserv. Genet. 16: 15-29. doi:10.1007/s10592-014-0636-6.

Bachman, R.A. 1984. Foraging behavior of free-ranging wild and hatchery brown trout in a stream. Trans. Am. Fish. Soc. 113: 1-32. doi:10.1577/15488659(1984)113<1:FBOFWA $>2.0 . C O ; 2$.

Baird, O.E., and Krueger, C.C. 2003. Behavioral thermoregulation of brook and rainbow trout: comparison of summer habitat use in an Adirondack River, New York. Trans. Am. Fish. Soc. 132: 1194-1206. doi:10.1577/T02-127.

Baldwin, N.S. 1957. Food consumption and growth of brook trout at different temperatures. Trans. Am. Fish. Soc. 86: 323-328. doi:10.1577/15488659(1956)86[323:FCAGOB]2.0.CO;2.

Baltz, D.M., Moyle, P.B., and Knight, N.J. 1982. Competitive interactions between benthic stream fishes, riffle sculpin, Cottus gulosus, and speckled dace, Rhinichthys osculus. Can. J. Fish. Aquat. Sci. 39: 1502-1511. doi: 10.1139/f82-202.

Barreto, R.E., and Volpato, G.L. 2004. Caution for using ventilator frequency as an indicator of stress in fish. Behav. Process. 66: 43-51. doi:10.1016/j.beproc.2004.01.001.

Bates, D., Maechler, M., Bolker, B., and Walker, S. 2015. Fitting linear mixed-effects models using lme4. J. Stat. Soft. 67: 1-48. doi:10.18637/jss.v067.i01.

Beamish, F.W.H. 1964. Respiration of fishes with special emphasis on standard oxygen consumption: II. Influence of weight and temperature on respiration of several species. Can. J. Zool. 42: 177-188. doi:10.1139/z64-016. 
Benda, L., Poff, N.L., Miller, D., Dunne, T., Reeves, G., Pess, G., and Pollock, M. 2004. The network dynamics hypothesis: how channel networks structure riverine habitats. BioScience 54: 413-427. doi:10.1641/0006-3568(2004)054[0413:TNDHHC]2.0.CO;2.

Biro, P. 1998. Staying cool: behavioral thermoregulation during summer by young-of-year brook trout in a lake. Trans. Am. Fish. Soc. 127: 212-222. doi:10.1577/15488659(1998) $127<0212:$ SCBTDS>2.0.CO;2.

Bolker, B.M, Brooks, M.E., Clark, C.J., Geange, S.W., Poulsen, J.R., Stevens, H.H., and White, J.S. 2009. Generalized linear mixed models: a practical guide for ecology and evolution. Trends Ecol. Evol. 24: 127-135. doi:10.1016/j.tree.2008.10.008.

Brunke, M., and Gonser, T. 1997. The ecological significance of exchange processes between rivers and groundwater. Freshwater Biol. 37: 1-33. doi:10.1046/j.13652427.1997.00143.x.

Cairns, M.A., Garton, R.R., and Tubb, R.A. 1982. Use of fish ventilation frequency to estimate chronically safe toxicant concentrations. Trans. Am. Fish. Soc. 111: 70-77. doi:10.1577/1548-8659(1982)111<70:UOFVFT>2.0.CO;2.

Carlson, S.M., Hendry, A.P., and Letcher, B.H. 2007. Growth rate differences between resident native brook trout and non-native brown trout. J. Fish Biol. 71: 1430-1447. doi:10.1111/j.1095-8649.2007.01615.x.

Carmona-Catot, G., Magellan, K., and García-Berthou, E. 2013. Temperature-specific competition between invasive mosquitofish and an endangered cyprinodontid fish. PLoS One 8: e54724. doi:10.1371/journal.pone.0054734. 
531 Chadwick, J.G., Jr., Nislow, K.H., and McCormick, S.D. 2015. Thermal onset of cellular and 532 endocrine stress responses correspond to ecological limits in brook trout, an iconic cold-

Chu, C., Jones, N.E., Mandrak, N.E., Piggott, A.R., and Minns, C.K. 2008. The influence of air temperature, groundwater discharge, and climate change on the thermal diversity of stream fishes in Ontario watersheds. Can. J. Fish. Aquat. Sci. 65: 297-308. doi:10.1139/F08-007.

Cucherousset, J., Aymes, J.C., Poulet, N., Santoul, F., and Céréghino, R. 2008. Do native brown trout and non-native brook trout interact reproductively? Naturwissenschaften 95: 647654. doi:10.1007/s00114-008-0370-3.

Cucherousset, J., and Olden, J.D. 2011. Ecological impacts of non-native freshwater fishes. Fisheries 35: 215-230. doi:10.1080/03632415.2011.574578.

Connell, J.H. 1983. On the prevalence and relative importance of interspecific competition: evidence from field experiments. Am. Nat. 122: 661-696. doi:10.1086/284165.

Constantz, J., Thomas, C.L., and Zellweger, G. 1994. Influence of diurnal variations in stream temperature on streamflow loss and groundwater recharge. Water Resour. Res. 30:32533264. doi:10.1029/94WR01968.

Cooper, E.L. 1952. Rate of exploitation of wild eastern brook trout and brown trout populations in the Pigeon River, Otsego County, Michigan. Trans. Am. Fish. Soc. 81: 224-234. doi:10.1577/1548-8659(1951)81[224:ROEOWE]2.0.CO;2.

Cunjak, R.A., and Power, G. 1986. Winter habitat utilization by stream resident brook trout (Salvelinus fontinalis) and brown trout (Salmo trutta). Can. J. Fish. Aquat. Sci. 43: 19701981. doi:10.1139/f86-242. 
554 Curry, R.A., and Noakes, D.L.G. 1995. Groundwater and the selection of spawning sites by

555 brook trout (Salvelinus fontinalis). Can. J. Fish. Aquat. Sci. 52: 1733-1740.

556 doi:10.1139/f95-765.

557

558

559

560

561

562

563

564

565

566

567

568

569

570

571

572

573

574

575

576

DeStaso, J., and Rahel, F.J. 1994. Influence of water temperature on interactions between juvenile Colorado cutthroat trout and brook trout in a laboratory stream. Trans. Am. Fish. Soc. 123: 289-297. doi:10.1577/1548-8659(1994)123<0289:IOWTOI>2.3.CO;2.

DeWald, L., and Wilzbach, M.A. 1992. Interactions between native brook trout and hatchery brown trout: effects on habitat use, feeding, and growth. Trans. Am. Fish. Soc. 121: 287296. doi:10.1577/1548-8659(1992)121<0287:IBNBTA>2.3.CO;2.

Dickson, T.A., and MacCrimmon, H.R. 1982. Influence of hatchery experience on growth and behavior of juvenile Atlantic salmon (Salmo salar) within allopatric and sympatric stream populations. Can. J. Fish. Aquat. Sci. 39: 1453-1458. doi:10.1139/f82-196.

Didrikas, T., and Hansson, S. 2008. Effects of light intensity on activity and pelagic dispersion of fish: studies with a seabed-mounted echosounder. ICES J. Mar. Sci. 66: 388-395. doi:10.1093/icesjms/fsn173.

Dugdale, S.J., Bergeron, N.E., and St-Hilaire, A. 2013. Temporal variability of thermal refuges and water temperature patterns in an Atlantic salmon river. Rem. Sens. Environ. 136: 358-373. doi:10.1016/j.rse.2013.05.018.

Dugdale, S.J., Bergeron, N.E., and St-Hilaire, A. 2015. Spatial distribution of thermal refuges analyzed in relation to riverscape hydromorphology using airborne thermal infrared imagery. Rem. Sens. Environ. 160: 43-55. doi:10.1016/j.rse.2014.12.021.

Dunning, J.B., Danielson, B.J., and Pulliam, H.R. 1992. Ecological processes that affect populations in complex landscapes. Oikos 65: 169-175. doi:10.2307/3544901. 
577 Dunson, W.A., and Travis, J. 1991. The role of abiotic factors in community organization. Am.

578

579

580

581

582

583

584

585

586

587

588

589

590

591

592

593

594

595

596

597 Nat. 138: 1067-1091. doi:10.1086/285270.

Eaton, J.G., McCormick, J.H., Goodno, B.E., O’Brien, D.G., Stefan, H.G., Hondzo, M., and Scheller, R.M. 1995. A field information-based system for estimating fish temperature tolerances. Fisheries 20: 10-18. doi:10.1577/15488446(1995)020<0010:AFISFE>2.0.CO;2.

Ebersole, J.L., Liss, W.J., and Frissell, C.A. 2001. Relationship between stream temperature, thermal refugia and rainbow trout Oncorhynchus mykiss abundance in arid-land streams in the northwestern United States. Ecol. Freshw. Fish 10: 1-10. doi:10.1034/j.16000633.2001.100101.x.

Ebersole, J.L., Liss, W.J., and Frissell, C.A. 2003. Thermal heterogeneity, stream channel morphology, and salmonid abundance in northeastern Oregon streams. Can. J. Fish. Aquat. Sci. 60: 1266-1280. doi:10.1139/f03-107.

Economo, E.P. 2011. Biodiversity conservation in metacommunity networks: linking pattern and persistence. Am. Nat. 177: E167-E180. doi:10.1086/659946

Essington, T.E., Sorenson, P.W., and Paron, D.G. 1998. High rate of redd superimposition by brook trout (Salvelinus fontinalis) and brown trout (Salmo trutta) in a Minnesota stream cannot be explained by habitat availability alone. Can. J. Fish. Aquat. Sci. 55: 23102316. doi:10.1139/f98-109.

Fausch, K.D. 1988. Tests of competition between native and introduced salmonids in streams: what have we learned? Can. J. Fish. Aquat. Sci. 45: 2238-2246. doi:10.1139/f88-260. 
Fausch, K.D. 1989. Do gradient and temperature affect distributions of, and interactions between, brook charr (Salvelinus fontinalis) and other resident salmonids in streams? Physiol. Ecol. Japan 1: 303-322.

Fausch, K.D. 1998. Interspecific competition and juvenile Atlantic salmon (Salmo salar): on testing effects and evaluating the evidence across scales. Can. J. Fish. Aquat. Sci. 55 (supplement 1): 218-231. doi:10.1139/d98-006.

Fausch, K.D., and White, R.J. 1981. Competition between brook trout (Salvelinus fontinalis) and brown trout (Salmo trutta) for positions in a Michigan stream. Can. J. Fish. Aquat. Sci. 38: 1220-1227. doi: 10.1139/f81-164.

Fausch, K.D., and White, R.J. 1986. Competition among juveniles of coho salmon, brook trout, and brown trout in a laboratory stream. Trans. Am. Fish. Soc. 115: 363-381.

Fausch, K.D., Torgersen, C.E., Baxter, C.V., and Li, H.W. 2002. Landscapes to riverscapes: bridging the gap between research and conservation of stream fishes. BioScience 52: 483-498. doi:10.1577/1548-8659(1986)115<363:CAJOCS>2.0.CO;2.

Flebbe, P.A. 1994. A regional view of the margin: salmonid abundance and distribution in the southern Appalachian mountains of North Carolina and Virginia. Trans. Am. Fish. Soc. 123: 657-667. doi:10.1577/1548-8659(1994)123<0657:ARVOTM>2.3.CO;2.

Frissell, C.A., Liss, W.J., Warren, C.E., and Hurley, M.D. 1986. A hierarchical framework for stream habitat classification: viewing streams in a watershed context. Environ. Manage. 10: 199-214. doi:10.1007/bf01867358.

Fry F.E.J., Hart, S.A., and Walker K.F. 1946. Lethal temperature relations for a sample of young speckled trout, Salvelinus fontinalis. Univ. Toronto Biol. Ser. 54: 9-35. 
620 Gard, R., and Flittner, G.A. 1974. Distribution and abundance of fishes in Sagehen Creek, 621 California. J. Wildl. Manage. 38: 347-358. doi:10.2307/3800744.

622 623 624 625 626 627 628 629 630 631 632 633 634 635 636 637 638 639 640 641 642

Hartman, G.F. 1963. Observations on behavior of juvenile brown trout in a stream aquarium during winter and spring. J. Fish. Res. Board Can. 20: 769-787. doi:10.1139/f63-051.

Hartman, K.J., and Cox, M.K. 2008. Refinement and testing of a brook trout bioenergetics model. Trans. Am. Fish. Soc. 137: 357-363. doi:10.1577/t05-243.1.

Harvey, J.W., and Bencala, K.E. 1993. The effect of streambed topography on surfacesubsurface water exchange in mountain catchments. Water Resour. Res. 29: 89-98. doi: 10.1029/92wr01960.

Hearn, W.E. 1987. Interspecific competition and habitat segregation among stream-dwelling trout and salmon: a review. Fisheries 12: 24-31. doi:10.1577/15488446(1987)012<0024:icahsa $>2.0 . c 0 ; 2$.

Hitt, N.P., and Roberts, J.R. 2012. Hierarchical spatial structure of stream fish colonization and extinction. Oikos 121: 127-137. doi:10.1111/j.1600-0706.2011.19482.x.

Hoxmeier, R.J.H., and Dieterman, D.J. 2013. Seasonal movement, growth and survival of brook trout in sympatry with brown trout in Midwestern US streams. Ecol. Freshw. Fishes 22: 530-542. doi:10.1111/eff.12051.

Hoxmeier, R.J.H., and Dieterman, D.J. 2016. Long-term population demographics of native brook trout following manipulative reduction of an invader. Biol. Invas. 18: 2911-2922. doi:10.1007/s10530-016-1182-6.

Hudy, M., Thieling, T.M., Gillespie, N., and Smith, E.P. 2008. Distribution, status, and land use characteristics of subwatersheds within the native range of brook trout in the eastern United States. N. Am. J. Fish. Manage. 28: 1069-1085. doi:10.1577/m07-017.1. 
643 Hutchinson, M.J., and Iwata, M. 1997. A comparative analysis of aggression in migratory and

644

645

646

647

648

649

650

651

652

653

654

655

656

657

658

659

660

661

662

663 non-migratory salmonids. Environ. Biol. Fish. 50: 209-215. doi:10.1023/A:1007327400284.

Isaak, D.J., Young, M.K., Luce, C.H., Hostetler, S.W., Wenger, S.J., Peterson, E.E., Ver Hoef, J.M., Groce, M.C., Horan, D.L., and Nagel, D.E. 2016. Slow climate velocities of mountain streams portend their role as refugia for cold-water biodiversity. Proc. Natl. Acad. Sci. U. S. A. 113: 4374-4379. doi:10.1073/pnas.1522429113.

Jenkins, T.M. Jr., Diehl, S., Kratz, K.W., and Cooper, S.D. 1999. Effects of population density on individual growth of brown trout in streams. Ecology 80: 941-956. doi:10.1890/00129658(1999)080\%5B0941:EOPDOI\%5D2.0.CO;2.

Job, S.V. 1955. The oxygen consumption of Salvelinus fontinalis. University of Toronto Press. Toronto, Ontario.

Jonsson, D. 2009. Temperature dependent competitive interactions between Arctic char (Salvelinus alpinus) and brown trout (Salmo trutta). M.Sc. thesis. Umeå University, Sweden.

Kanno, Y., Letcher, B.H., Coombs, J.A., Nislow, K.H., and Whiteley, A.R. 2014a. Linking movement and reproductive history of brook trout to assess habitat connectivity in a heterogenous stream network. Fresh. Bio. 59: 142-154. doi:10.1111/fwb.12254.

Kanno, Y., Vokoun, J.C., and Letcher, B.H. 2014b. Paired stream-air temperature measurements reveal fine-scale thermal heterogeneity within headwater brook trout stream networks. River Res. Applic. 30: 745-755. doi:10.1002/rra.2677. 
664 Kanno, Y., Letcher, B.H., Hitt, N.P., Boughton, D.A., Wofford, J.E.B., and Zipkin, E.F. 2015.

665 Seasonal weather patterns drive population vital rates and persistence in a stream fish.

666 Global Change Biol. 21: 1856-1870. doi:10.1111/gcb.12837.

667

668

669

670

671

672

673

674

675

676

677

678

679

680

681

682

683

684

685

686

Kaya, C.M., Kaeding, L.R., and Burkhalter, D.E. 1977. Use of a cold-water refuge by rainbow and brown trout in a geothermally heated stream. Prog. Fish-Cult. 39: 37-39. doi: 10.1577/1548-8659(1977)39[37:UOACRB]2.0.CO;2.

Keenleyside, M.H.A., and Yamamoto, F.T. 1962. Territorial behavior of juvenile Atlantic salmon (Salmo salar L.). Behaviour 19: 139-169. doi:10.1163/156853961x00231.

Kozar, M.D., McCoy, K.J., Weary, D.J., Field, M.S., Pierce, H.A., Schill, W.B., and Young, J.A. 2007. Hydrogeology and water quality of the Leetown Area, West Virginia. US Geological Survey Open File Report 2007-1358. US Geological Survey, Reston VA.

Kozel, S.J., and Hubert, W.A. 1989. Factors influencing the abundance of brook trout (Salvelinus fontinalis) in forested mountain streams. J. Freshw. Ecol. 5: 113-122. doi:10.1080/02705060.1989.9665219.

Kreuger, C.C., and May, B. 1991. Ecological and genetic effects of salmonid introductions in North America. Can. J. Fish. Aquat. Sci. 48(S1): 66-77. doi:10.1139/f91-305.

Kurylyk, B.L., MacQuarrie, K.T.B., and Voss, C.L. 2014a. Climate change impacts on the temperature and magnitude of groundwater discharge from shallow, unconfined aquifers. Water Resour. Res. 50: doi:10.1002/2013WR014588.

Kurylyk, B.L., MacQuarrie, K.T.B., Linnansarri, T., Cunjak, R.A., and Curry, R.A. $2014 b$. Preserving, augmenting, and creating cold-water thermal refugia in rivers: concepts derived from research on the Miramichi River, New Brunswick (Canada). Ecohydrol. 8: 1095-1108. doi:10.1002/eco.1566. 
Larson, G.L., and Moore, S.E. 1985. Encroachment of exotic rainbow trout into stream populations of native brook trout in the southern Appalachian mountains. Trans. Am. Fish. Soc. 114: 195-203. doi:10.1577/1548-8659(1985)114<195:EOERTI>2.0.CO;2.

Larson, G.L., Moore, S.E., and Carter, B. 1995. Ebb and flow of encroachment by nonnative rainbow trout in a small stream in the southern Appalachian mountains. Trans. Am. Fish. Soc. 124: 613-622. doi:10.1577/1548-8659(1995)124<0613:EAFOEB>2.3.CO;2.

Lee, R.M., and Rinne, J.N. 1980. Critical thermal maxima of five trout species in the southwestern United States. Trans. Am. Fish. Soc. 109: 632-635. doi:10.1577/15488659(1980)109<632:CTMOFT>2.0.CO;2.

MacCrimmon, H.R., and Campbell, J.S. 1969. World distribution of brook trout (Salvelinus fontinalis). J. Fish. Res. Board Can. 26: 1699-1725. doi:10.1139/f71-060.

McKenna, J.E., Slattery, M.T., and Clifford, K.M. 2013. Broad-scale patterns of brook trout responses to introduced brown trout in New York. N. Am. J. Fish. Manage 33: 12211235. doi:10.1080/02755947.2013.830998.

McMahon, T.E., Zale, A.V., Barrows, F.T., Selong, J.H., and Danehy, R.J. 2007. Temperature and competition between bull trout and brook trout: a test of the elevation refuge hypothesis. Trans. Am. Fish. Soc. 136: 1313-1326. doi:10.1577/T06-217.1.

Magoulick, D.D., and Wilzbach, M.A. 1998. Are native brook charr and introduced rainbow trout differentially adapted to upstream and downstream reaches? Ecol. Freshw. Fish 7: 167-175. doi:10.1111/j.1600-0633.1998.tb00183.x.

Marshall, T.L., and MacCrimmon, H.R. 1970. Exploitation of self-sustaining Ontario stream populations of brown trout (Salmo trutta) and brook trout (Salvelinus fontinalis). J. Fish. Res. Board Can. 27: 1087-1102. doi:10.1139/f70-124. 
710

711

712

713

714

715

716

717

718

719

720

721

722

723

724

725

726

727

728

729

730

731

732

Matthews, W.J., Gido, K.B., Garrett, G.P., Gelwick, F.P., Stewart, J.G., and Schaefer, J. 2006. Modular experimental riffle-pool stream system. Trans. Am. Fish. Soc. 135: 1559-1566. doi:10.1577/T05-202.1.

Meisner, J.D., Rosenfeld, J.S., and Regier, H.A. 1988. The role of groundwater in the impact of climate warming on stream salmonines. Fisheries 13: 2-8. doi:10.1577/15488446(1988)013<0002:TROGIT>2.0.CO;2.

Mesa, M.G. 1991. Variation in feeding, aggression, and position choice between hatchery and wild cutthroat trout in an artificial stream. Trans. Am. Fish. Soc. 120: 723-727. doi:10.1577/1548-8659(1991)120<0723:VIFAAP>2.3.CO;2.

Millidine, K.J., Metcalfe, N.B., and Armstrong, J.D. 2008. The use of ventilation frequency as an accurate indicator of metabolic rate in juvenile Atlantic salmon (Salmo salar). Can. J. Fish. Aquat. Sci. 65: 2081-2087. doi:10.1139/F08-118.

Moore, S.E., Ridley, B., and Larson, G.L. 1983. Standing crops of brook trout concurrent with removal of rainbow trout from selected streams in Great Smoky Mountains National Park. N. Am. J. Fish. Manage. 3: 72-80. doi: 10.1577/15488659(1983)3<72:SCOBTC $>2.0 . \mathrm{CO} ; 2$.

Moyle, P.B. 1969. Comparative behavior of young brook trout from domestic and wild origin. Prog. Fish-Cult. 31: 51-56. doi:10.1577/1548-8640(1969)31[51:CBOYBT]2.0.CO;2.

Nakagawa, S., and Schielzeth, H. 2013. A general and simple method for obtaining $R^{2}$ from generalized linear mixed-effects models. Meth. Ecol. Evol. 4: 133-142. doi:10.1111/j.2041-210x.2012.00261.x.

Newman, M.A. 1956. Social behavior and interspecific competition in two trout species. Physiol. Zool. 29: 64-81. doi:10.1086/physzool.29.1.30152381. 
733 Öhlund, G., Nordwall, F., Degerman, E., and Eriksson, T. 2008. Life history and large-scale 734 habitat use of brown trout (Salmo trutta) and brook trout (Salvelinus fontanalis) -

735 736

737 738 739 740 741

742 743 744 745 746 747 748 749 750 751 752 753 754 755 implications for species replacement patterns. Can. J. Fish. Aquat. Sci. 65: 633-644. doi:10.1139/f08-00.

Payne, L.X., Schindler, D.E., Parrish, J.K., and Temple, S.A. 2005. Quantifying spatial pattern with evenness indices. Ecol. Appl. 15:507-520. doi:10.1890/03-5029.

Petty, J.T., Hansbarger, J.L., Huntsman, B.M., and Mazik, P.M. 2012. Brook trout movement in response to temperature, flow, and thermal refugia within a complex Appalachian riverscape. Trans. Am. Fish. Soc. 141: 1060-1073. doi:10.1080/00028487.2012.681102.

Poole, G.C., Stanford, J.A., Running, S.W., and Frissell, C.A. 2006. Multiscale geomorphic drivers of groundwater flow paths: subsurface hydrologic dynamics and hyporheic habitat diversity. J. North Am. Benthol. Soc. 25: 288-303. doi:10.1899/08873593(2006)25[288:mgdogf]2.0.co;2.

Rahel, F.J., and Hubert, W.A. 1991. Fish assemblages and habitat gradients in a Rocky Mountain - Great Plains stream: biotic zonation and additive patterns of community change. Trans. Am. Fish. Soc. 120: 319-332. doi:10.1577/1548-8659(1991)120<0319:faahgi >2.3.co;2.

Rahel, F.J., Bierwagen, B., and Taniguchi, Y. 2008. Managing aquatic species of conservation concern in the face of climate change and invasive species. Cons. Biol. 22: 551-561. doi:10.1111/j.1523-1739.2008.00953.x.

Schlosser, I.J. 1991. Stream fish ecology: a landscape perspective. BioScience 41: 704-712. doi: $10.2307 / 1311765$.

Sheldon, A.S. 1968. Species diversity and longitudinal succession in stream fishes. Ecology 49: 193-198. doi:10.2307/1934447. 
756 Simpson, E.H. 1949. Measurement of diversity. Nature 163: 688. doi:10.1038/163688a0.

757 Snucins, E.J., and Gunn, J.M. 1995. Coping with a warm environment: behavioral

758

759

760

761

762

763

764

765

766

767

768

769

770

771

772

773

774

775

776

777

thermoregulation by lake trout. Trans. Am. Fish. Soc. 124: 118-123. doi:10.1577/15488659(1995) $124<0118$ :cwaweb $>2.3$. co; 2 .

Snyder, C.D., Hitt, N.P., and Young, J.A. 2015. Accounting for the influence of groundwater on the thermal sensitivity of headwater streams to climate change. Ecol. Appl. 25: 13971419. doi:10.1890/14-1354.1.

Sorensen, P.W., Cardwell, J.R., Essington, T., and Weigel, D.E. 1995. Reproductive interactions between sympatric book and brown trout in a small Minnesota stream. Can. J. Fish. Aquat. Sci. 52: 1958-1965.

Steffy, L.Y., McGinty, A.L., Welty, C., and Kilham, S.S. 2004. Connecting ground water influxes with fish species diversity in an urbanized watershed. J. Am. Water Resour. Assoc. 40: 1269-1275.

Strange, R.J., and Habera, J.W. 1998. No net loss of brook trout distribution in areas of sympatry with rainbow trout in Tennessee streams. Trans. Am. Fish. Soc. 127: 434-440.

Stranko, S.A., Hilderbrand, R.H., Morgan R.P., Staley, M.W., Becker, A.J., Roseberry-Lincoln, A., Perry, E.S., and Jacobson, P.T. 2008. Brook trout declines with land cover and temperature changes in Maryland. North Am. J. Fish. Manage. 28: 1223-1232.

Taniguchi, Y., Rahel, F.J., Novinger, D.C., and Gerow, K.G. 1998. Temperature mediation of competitive interactions among three fish species that replace each other along longitudinal stream gradients. Can. J. Fish. Aquat. Sci. 55: 1894-1901. doi:10.1139/f98072. 
778 Taniguchi, Y., and Nakano, S. 2000. Condition-specific competition: implications for the

779

780 781

782

783

784

785

786

787

788

789

790

791

792

793

794

795

796

797

798

799

800

altitudinal distribution of stream fishes. Ecology 81: 2027-2039. doi:10.2307/177290.

Torgerson, C.E., Price, D.M., Li, H.W., and McIntosh, B.A. 1999. Multiscale thermal refugia and stream habitat associations of chinook salmon in northeastern Oregon. Ecol. Appl. 9: 301-319. doi:10.2307/2641187.

Tylianakis, J.M., Didham, R.K., Bascompte, J., and Wardle, D.A. 2008. Global change and species interactions in terrestrial ecosystems. Ecol. Lett. 11: 1351-1363. doi:10.1111/j.1461-0248.2008.01250.x.

Utz, R., and Hartman, K.J. 2009. Density-dependent individual growth and size dynamics of central Appalachian brook trout (Salvelinus fontinalis). Can. J. Fish. Aquat. Sci. 66: 1072-1080. doi:10.1139/F09-063.

Van der Putten, W.H., Macel, M., and Visser, M.E. 2010. Predicting species distribution and abundance responses to climate change: why it is essential to include biotic interactions across trophic levels. Philos. Trans. R. Soc., B 365: 2025-2034. doi:10.1098/rstb.2010.0037.

Vincent, R.E. 1960. Some influences of domestication upon three stocks of brook trout (Salvelinus fontinalis, Mitchill). Trans. Am. Fish. Soc. 89: 35-52. doi:10.1577/15488659(1960)89[35:siodut]2.0.co;2.

Vincent, R.E., and Miller, W.H. 1969. Altitudinal distribution of brown trout and other fishes in a headwater tributary of the South Platte River, Colorado. Ecology 50:464-466. doi: $10.2307 / 1933899$.

Vonesh, E.F., Chinchilli, V.M., and Pu, K. 1996. Goodness-of-fit in generalized nonlinear mixed-effects models. Biometrics 52: 572-587. doi:10.2307/2532896. 
801 Wagner, T., Deweber, J.T., Detar, J. and Sweka, J.A. 2013. Landscape-scale evaluation of 802 803 804 805 806 807 asymmetric interactions between brown trout and brook trout using two-species occupancy models. Trans. Am. Fish. Soc. 142: 353-361. doi:10.1080/00028487.2012.734892.

Walker, R.L., Wood, C.M., and Bergman, H.L. 1988. Effects of low pH and aluminum on ventilation in the brook trout (Salvelinus fontinalis). Can. J. Fish. Aquat. Sci. 45: 16141622. doi:10.1139/f88-191.

Warren, D.R., Robinson, J.M., Josephson, D.C., Sheldon, D.R., and Kraft, C.E. 2012. Elevated summer temperatures delay spawning and reduce redd construction for resident brook trout (Salvelinus fontinalis). Global Change Biol. 18: 1804-1811. doi:10.1111/j.13652486.2012.02670.x.

Waters, T.F. 1983. Replacement of brook trout by brown trout over 15 years in a Minnesota stream: production and abundance. Trans. Am. Fish. Soc. 112: 137-146. doi:10.1577/1548-8659(1983)112<137:robtbb $>2.0 . c 0 ; 2$.

Waters, T.F. 1999. Long-term trout production dynamics in Valley Creek, Minnesota. Trans. Am. Fish. Soc. 128: 1151-1162. doi:10.1577/1548-8659(1999)128<1151:1ttpdi>2.0.co;2.

Weber, E.D., and Fausch, K.D. 2003. Interactions between hatchery and wild salmonids in streams: differences in biology and evidence for competition. Can. J. Fish. Aquat. Sci. 60: 1018-1036. doi:10.1139/f03-087.

Wenger, S.J., Isaak, D.J., Luce, C.H., Neville, H.M., Fausch, K.D., Dunham, J.B., Dauwalter, D.C., Young, M.K., Elsner, M.M., Rieman, B.E., A.F. Hamlet, and J.E. Williams. 2011. Flow regime, temperature, and biotic interactions drive differential declines of trout 
823

824

825 Wehrly, K.E., L. Wang, and M. Mitro. 2007. Field-based estimates of thermal tolerance limits

826

827

828 White, S.L. and C. Gowan. 2013. Brook trout use individual recognition and transitive inference 829

species under climate change. Proc. Natl. Acad. Sci. U. S. A. 108: 14175-14180. doi: 10.1073/pnas.1103097108.

for trout: incorporating exposure time and temperature fluctuation. Trans. Am. Fish. Soc. 136: 365-374. doi:10.1577/t06-163.1.

to determine social rank. Behav. Ecol. 24: 63-69. doi:10.1093/beheco/ars136. 


\section{Figure captions}

831

Fig. 1. Experimental stream design. Two replicate streams are shown with pools as circles and riffles as troughs between pools. Arrows indicate recirculating flow direction through the overflow sump (S), system pump and filters (PF), heating unit (HE), chilling unit (C). The

835 locations of groundwater upwelling $(\mathrm{GW})$ and belt feeders $(\mathrm{B})$ created spatial structure for 836 thermal and forage habitats.

Fig. 2. Observed hourly temperatures during experimental trials. Solid lines show ambient stream temperatures and dashed lines show upwelling water temperatures measured near substrates over 6 experimental trials (replicates). Horizontal dashed lines show target temperature levels $\left(14,17,20,23^{\circ} \mathrm{C}\right)$, and vertical dashed lines indicate midnight. Auxiliary

842 measures of upwelling zone temperature are indicated by " $\mathrm{x}$ ".

Fig. 3. (a) Upwelling habitat use for allopatric brook trout (A, filled), sympatric brook trout (S, grey) with sympatric brown trout (B, open), and total sympatric populations (hatch-marks) across ambient temperature levels. Bars show mean values, and whiskers show 1 standard deviation

847 from the mean. (b) Effects of brown trout and temperature on brook trout upwelling habitat use.

848 Points indicate fitted model coefficients, and line segments indicate bootstrapped 95\%

849 confidence intervals. Line segment colors distinguish fixed and random effects. Upwelling zones 850 are mapped as GW in Fig. 1. 
852 Fig. 4. (a) Spatial evenness within streams for allopatric brook trout (A, filled), sympatric brook

853 trout (S, grey) with sympatric brown trout (B, open), and total sympatric populations (hatch-

854 marks) across ambient temperature levels. Bars show mean values, and whiskers show 1

855 standard deviation from the mean. (b) Effects of brown trout and temperature on brook trout

856 spatial evenness. Points indicate fitted model coefficients, and line segments indicate

857 bootstrapped 95\% confidence intervals. Line segment colors distinguish fixed and random

858 effects. Spatial evenness was calculated from a modification of Simpson's Index (equation 1).

859

860 Fig. 5. (a) Inter-tank movement rates for allopatric brook trout (A, filled), sympatric brook trout

861 (S, grey) with sympatric brown trout (B, open), and total sympatric populations (hatch-marks)

862 across ambient temperature levels. Bars show mean values, and whiskers show 1 standard

863 deviation from the mean. (b) Effects of brown trout and temperature on brook trout movement

864 rates. Points indicate fitted model coefficients, and line segments indicate bootstrapped 95\%

865 confidence intervals. Line segment colors distinguish fixed and random effects.

867 Fig. 6. (a) Aggressive behavior rates for allopatric brook trout (A, filled), sympatric brook trout

868 (S, grey) with sympatric brown trout (B, open), and total sympatric populations (hatch-marks)

869 across ambient temperature levels. Bars show mean values, and whiskers show 1 standard

870 deviation from the mean. (b) Effects of brown trout and temperature on brook trout aggressive

871 behavior rates. Points indicate fitted model coefficients, and line segments indicate bootstrapped

$87295 \%$ confidence intervals. Line segment colors distinguish fixed and random effects.

873 
874 Fig. 7. (a) Ventilation rates for allopatric brook trout (A, filled) and sympatric brook trout (S,

875 grey) with brown trout across ambient temperature levels. Bars show mean values, and whiskers

876 show 1 standard deviation from the mean. (b) Effects of brown trout and temperature on brook

877 trout ventilation rates. Points indicate fitted model coefficients, and line segments indicate

878 bootstrapped $95 \%$ confidence intervals. Line segment colors distinguish fixed and random 879 effects. 
880 Table 1. Water quality parameters measured across the range of experimental temperatures.

881 Median values are shown with median absolute deviation in parentheses. Data were collected

882 with a YSI Professional Plus Multiparameter Instrument ( $n=18$ per temperature level).

\begin{tabular}{lcccc}
\hline & \multicolumn{2}{c}{ Temperature } & \multicolumn{2}{c}{ Wilcoxon rank-sum test } \\
\cline { 2 - 5 } Variable & $\mathbf{1 4}^{\mathbf{0}} \mathbf{C}$ & $\mathbf{2 3}{ }^{\mathbf{0}} \mathbf{C}$ & $\boldsymbol{W}$ & $\boldsymbol{p}$ \\
\hline Conductivity $(\mu \mathrm{S} / \mathrm{cm})$ & $473(11.3)$ & $582(3.0)$ & 0 & $<0.0001$ \\
Dissolved oxygen $(\mathrm{mg} / \mathrm{L})$ & $8.5(0.3)$ & $8.3(0.4)$ & 240 & $<0.01$ \\
$\mathrm{pH}$ & $8.2(0.05)$ & $8.3(0.03)$ & 80 & $<0.01$ \\
\hline
\end{tabular}


884 Table 2. Coefficients of determination for linear mixed models. The marginal $R^{2}$ indicates 885 variance explained by brown trout (fixed effect), and the conditional $R^{2}$ indicates variance 886 explained by brown trout and temperature (fixed and random effects) (see Nakagawa and 887 Schielzeth 2013). The relative importance of temperature ranges from 0-1 and is calculated as 888 (conditional $R^{2}$ - marginal $R^{2}$ )/conditional $R^{2}$, and the relative importance of brown trout is 889 calculated as 1 minus the relative importance of temperature.

\begin{tabular}{|c|c|c|c|c|}
\hline $\begin{array}{c}\text { Response } \\
\text { variable }\end{array}$ & $\begin{array}{l}\text { Marginal } R^{2} \\
\text { (fixed effect) }\end{array}$ & $\begin{array}{c}\text { Conditional } \boldsymbol{R}^{2} \\
\text { (fixed and random } \\
\text { effects) }\end{array}$ & $\begin{array}{c}\text { Relative } \\
\text { importance of } \\
\text { temperature } \\
\text { (random effects) }\end{array}$ & $\begin{array}{c}\text { Relative } \\
\text { importance of } \\
\text { brown trout } \\
\text { (fixed effect) }\end{array}$ \\
\hline $\begin{array}{l}\text { Upwelling } \\
\text { habitat use }\end{array}$ & 0.347 & 0.540 & 0.357 & 0.643 \\
\hline $\begin{array}{l}\text { Spatial } \\
\text { evenness }\end{array}$ & 0.689 & 0.698 & 0.013 & 0.987 \\
\hline Movement & 0.370 & 0.377 & 0.019 & 0.981 \\
\hline Aggression & 0.0003 & 0.093 & 0.997 & 0.003 \\
\hline Ventilation & 0.0001 & 0.763 & 1.000 & $<0.001$ \\
\hline
\end{tabular}


891 Table 3. Correlation matrices for brook trout upwelling habitat use (UHU), brook trout spatial

892 evenness (SPE), brook trout movement rate (MOV), brook trout aggressive behavior rate (AGG),

893 and brook trout ventilation rate (VEN) in the presence and absence of brown trout across all

894 temperature levels. Upper diagonals contain Spearman correlation coefficients and lower

895 diagonals contain associated $p$-values. Coefficients with $p<0.05$ are indicated by *. Sample size

896 for allopatric and sympatric treatments included 24 observations (4 temperature levels x 6

897 replicates), respectively.

\begin{tabular}{|c|c|c|c|c|c|c|}
\hline Treatment & Variable & UHU & SPE & MOV & AGG & VEN \\
\hline \multicolumn{7}{|l|}{ Brown trout } \\
\hline \multirow[t]{5}{*}{ absent } & UHU & - & -0.15 & $-0.54 *$ & 0.20 & $0.44^{*}$ \\
\hline & SPE & 0.49 & & 0.02 & 0.07 & -0.24 \\
\hline & MOV & $<0.01$ & 0.93 & - & 0.17 & -0.22 \\
\hline & AGG & 0.36 & 0.76 & 0.43 & - & $0.51 *$ \\
\hline & VEN & 0.03 & 0.25 & 0.30 & 0.01 & - \\
\hline \multicolumn{7}{|l|}{ Brown trout } \\
\hline \multirow[t]{5}{*}{ present } & UHU & - & $-0.55^{*}$ & $-0.43 *$ & -0.09 & 0.21 \\
\hline & SPE & $<0.01$ & - & 0.25 & 0.09 & 0.08 \\
\hline & MOV & 0.03 & 0.25 & - & $0.55^{*}$ & 0.33 \\
\hline & AGG & 0.68 & 0.68 & $<0.01$ & - & $0.59 *$ \\
\hline & VEN & 0.34 & 0.72 & 0.12 & $<0.01$ & - \\
\hline
\end{tabular}


900

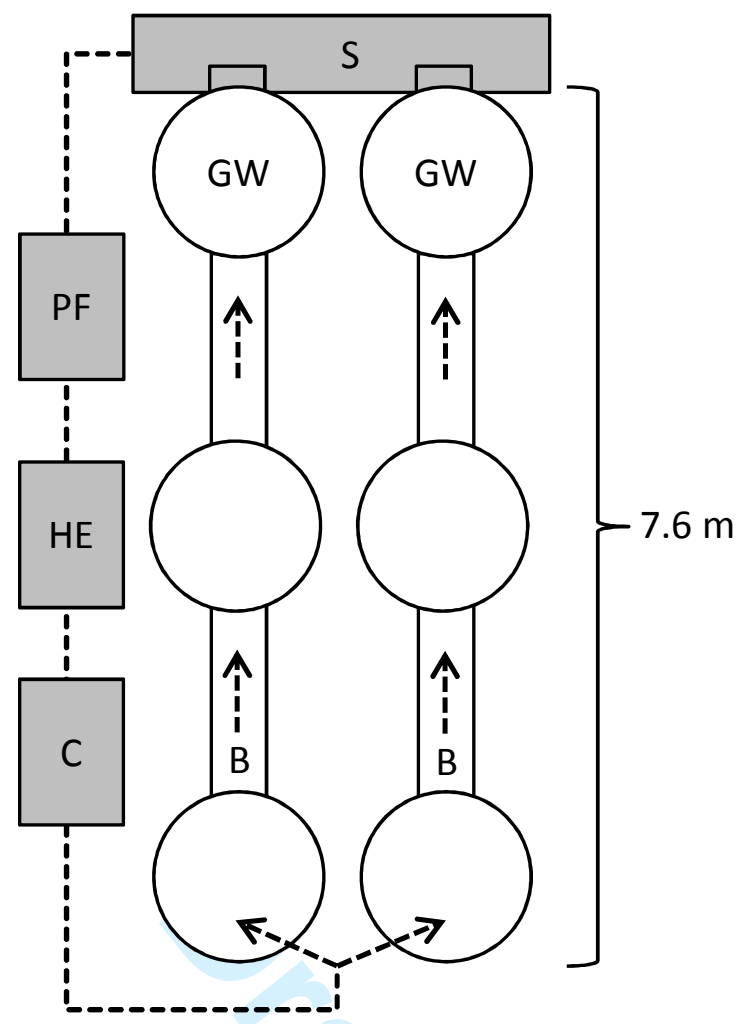


901

Trial 1: 20-23 April 2015

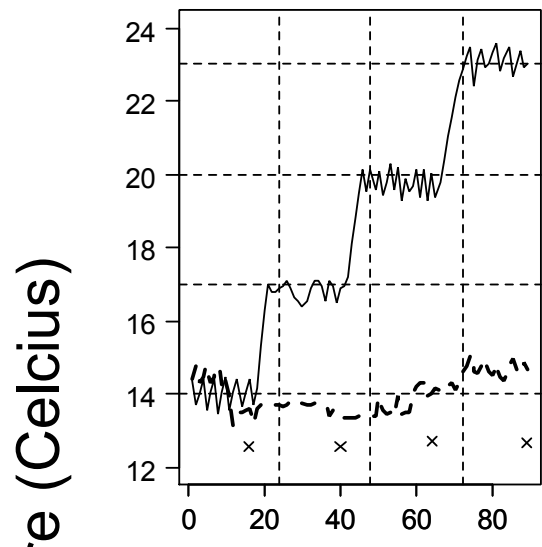

喜 $\quad$ Trial 4: 11-14 May 2015

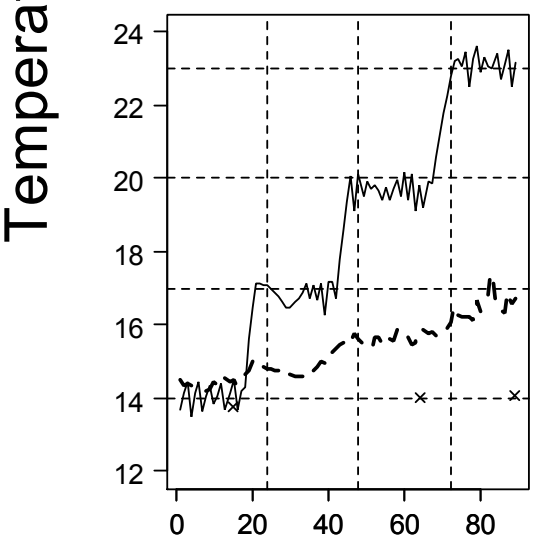

Trial 2: 27-30 April 2015

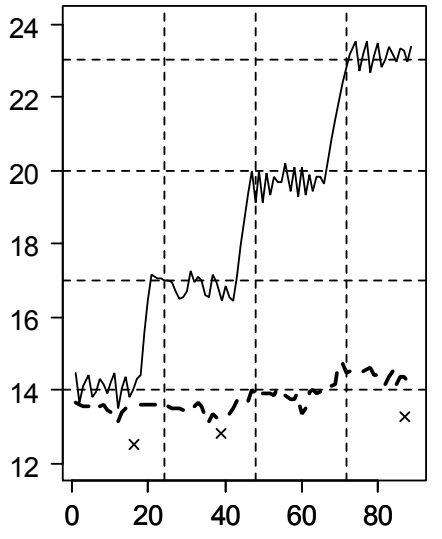

Trial 5: 18-21 May 2015

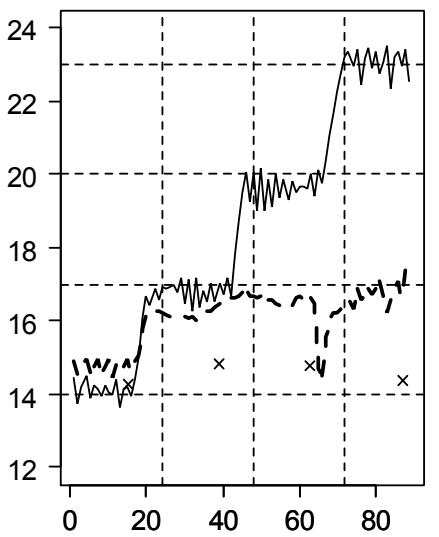

Time (hour)
Trial 3: 4-7 May 2015

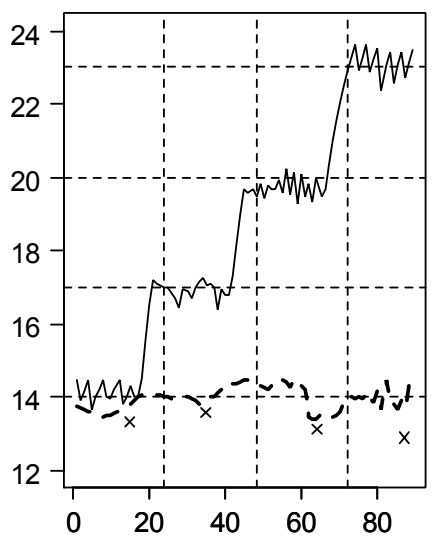

Trial 6: 25-28 May 2015

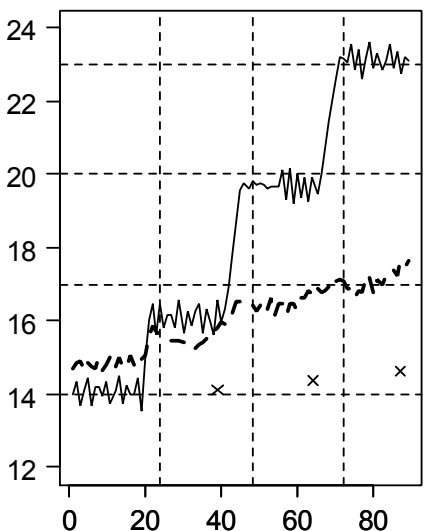




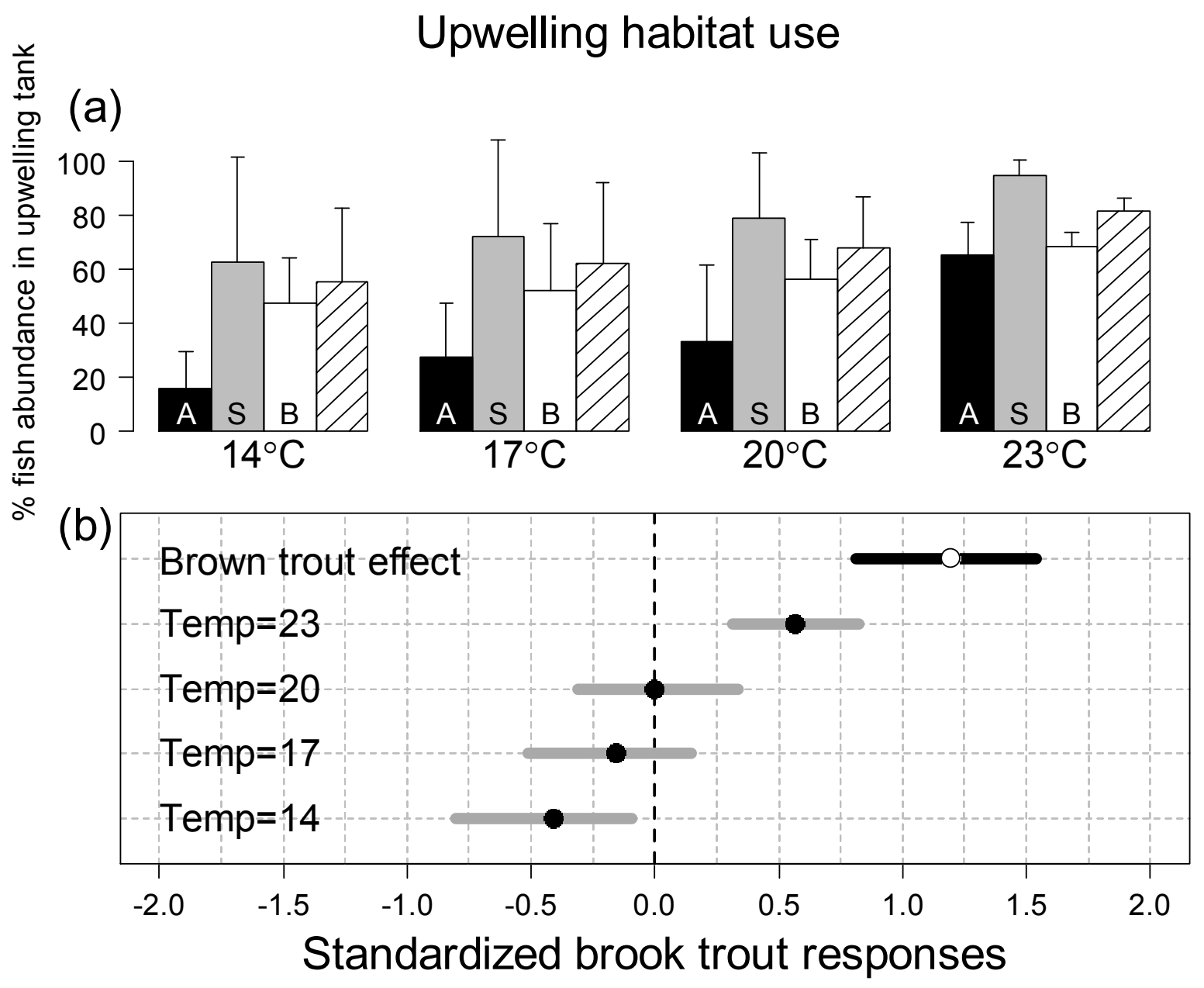


Spatial evenness

(a)
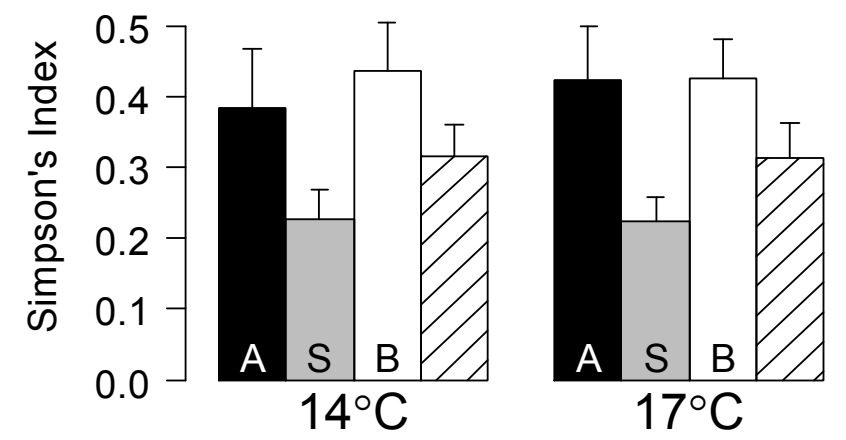

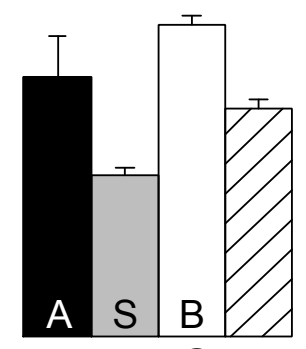

$20^{\circ} \mathrm{C}$
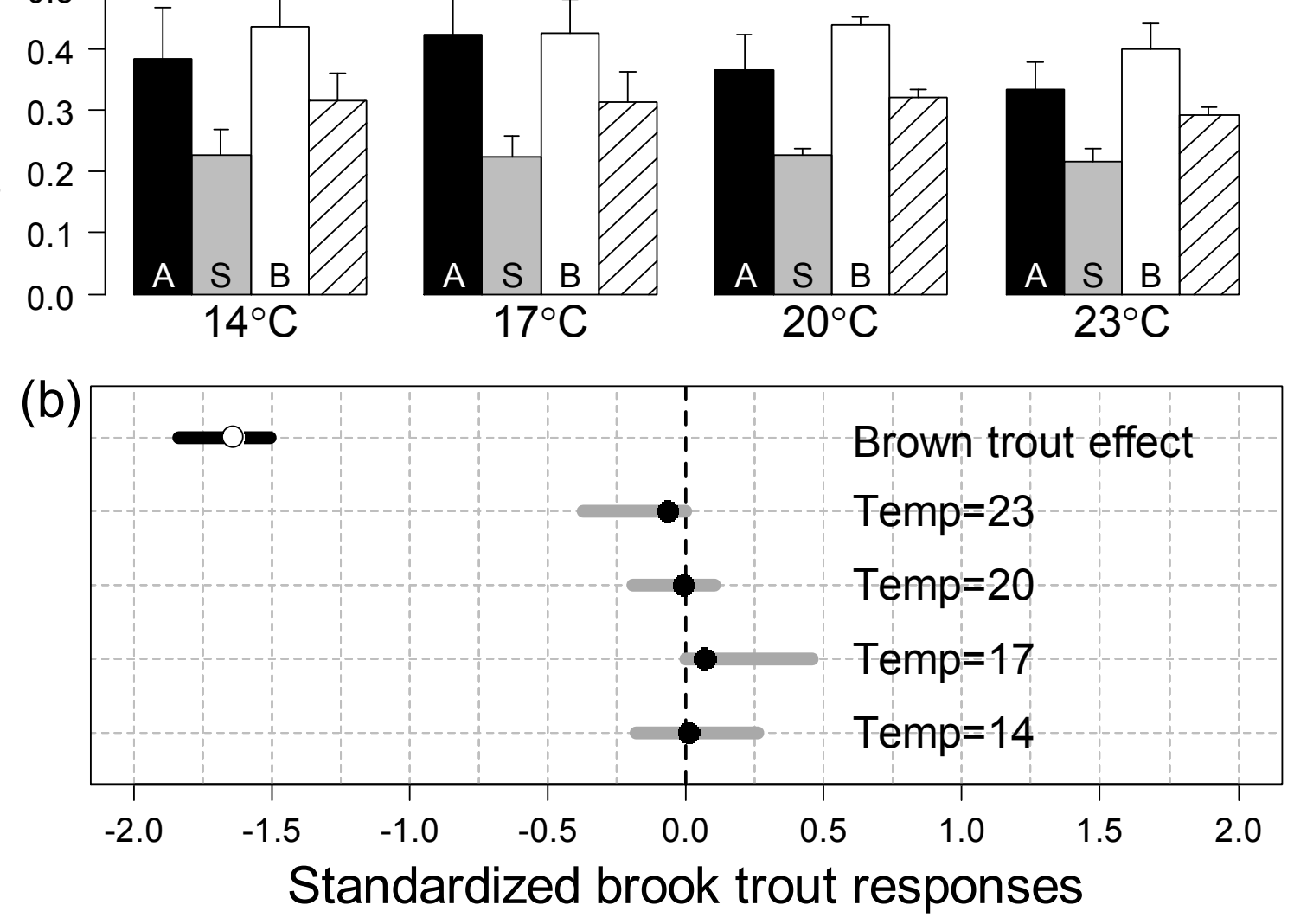

905

906 

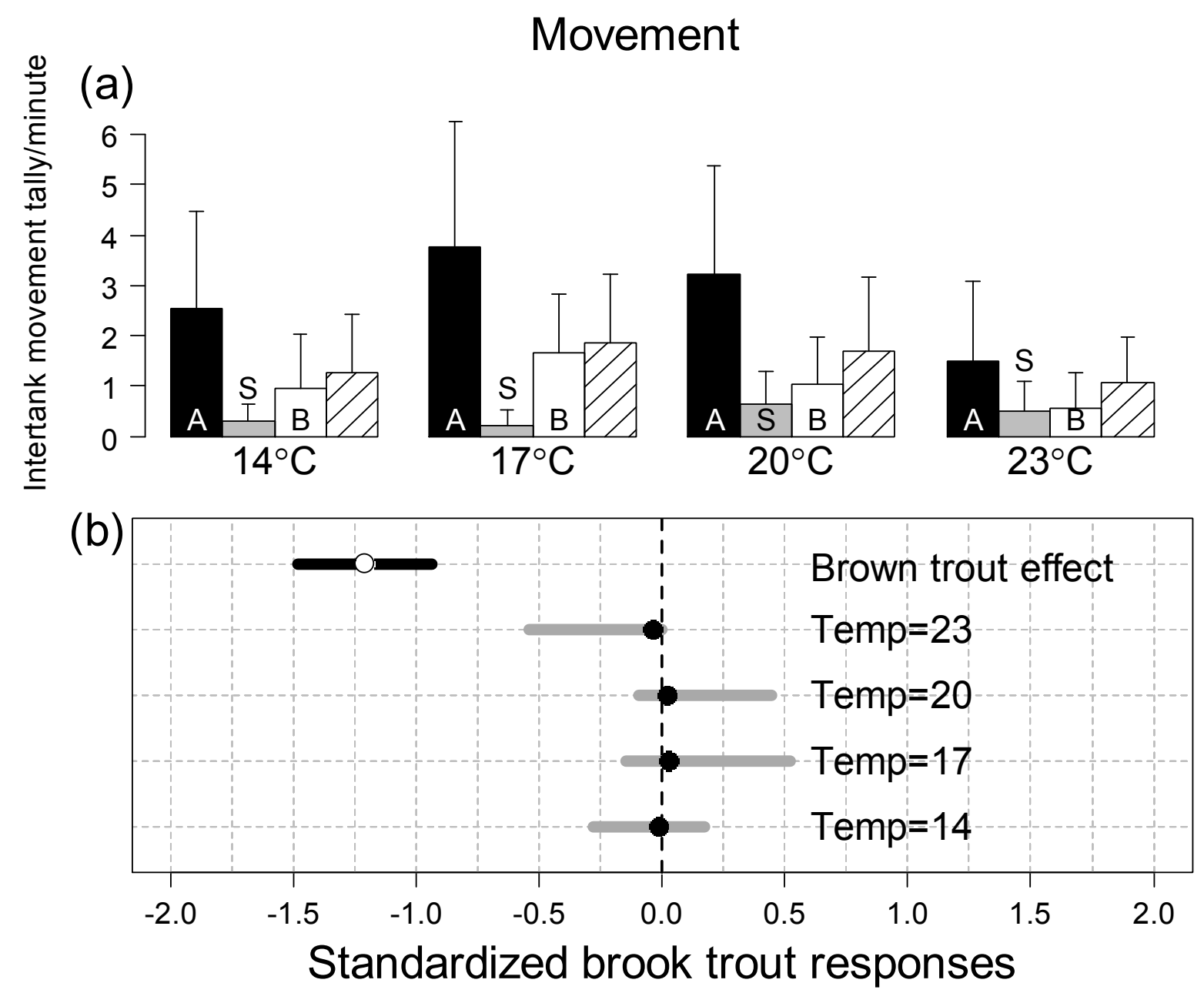


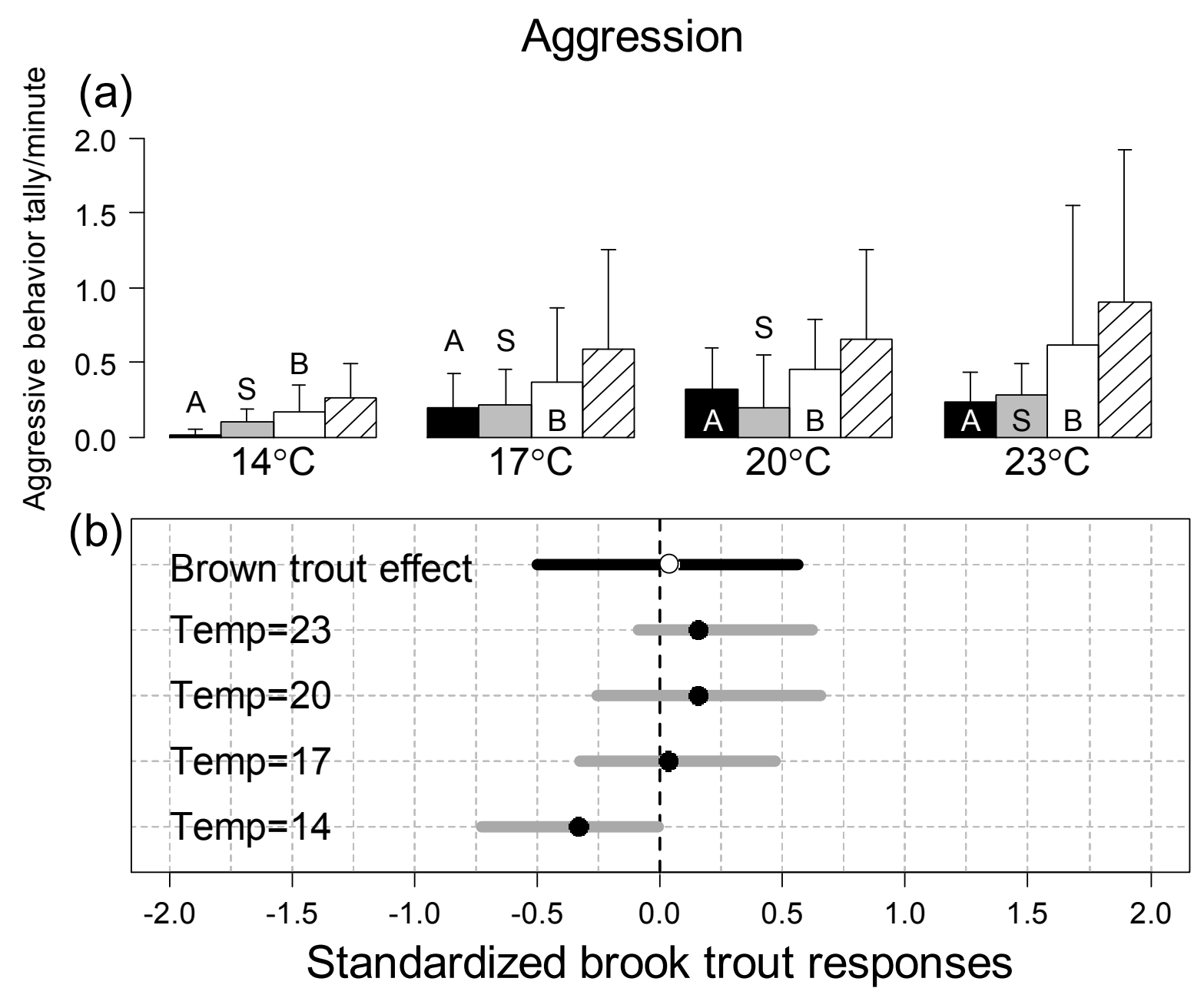




\section{Ventilation rate}
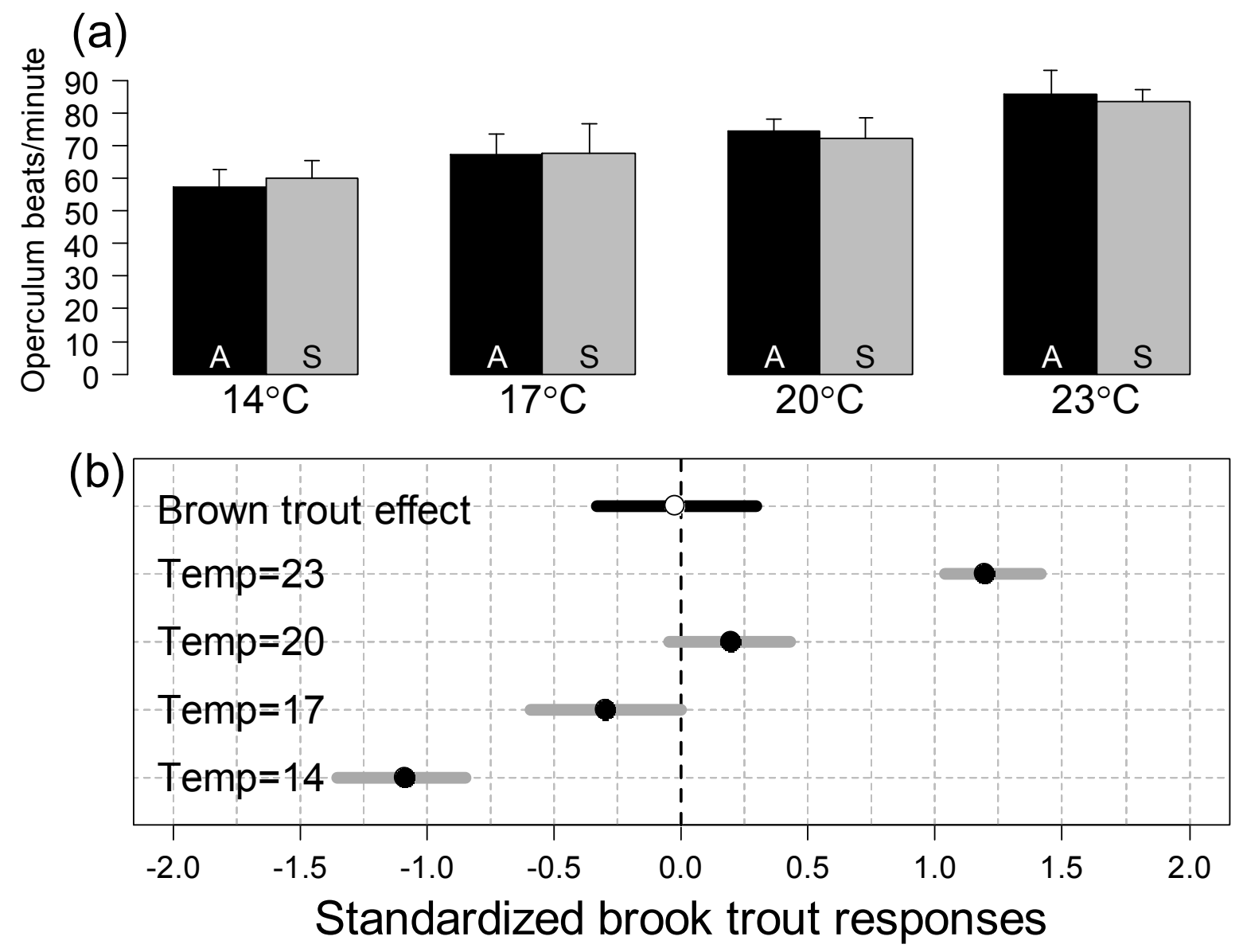

909 
Appendix A. Length-weight plots for brook trout and brown trout prior to experimental trials. A random subset of the individuals shown was used for experimental trials.

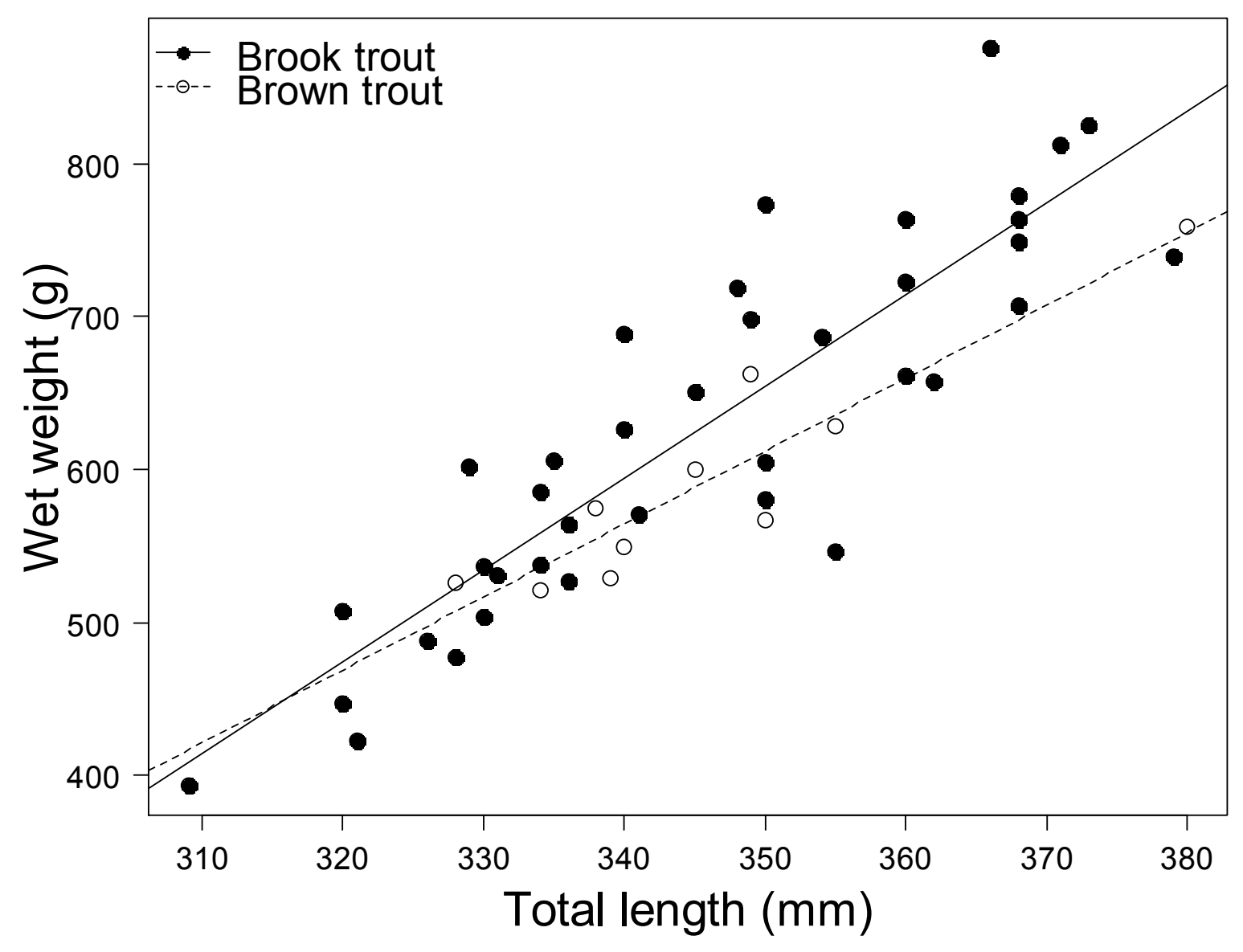


Appendix B. Photo of dye test showing coldwater upwelling from substrates in an experimental stream channel.

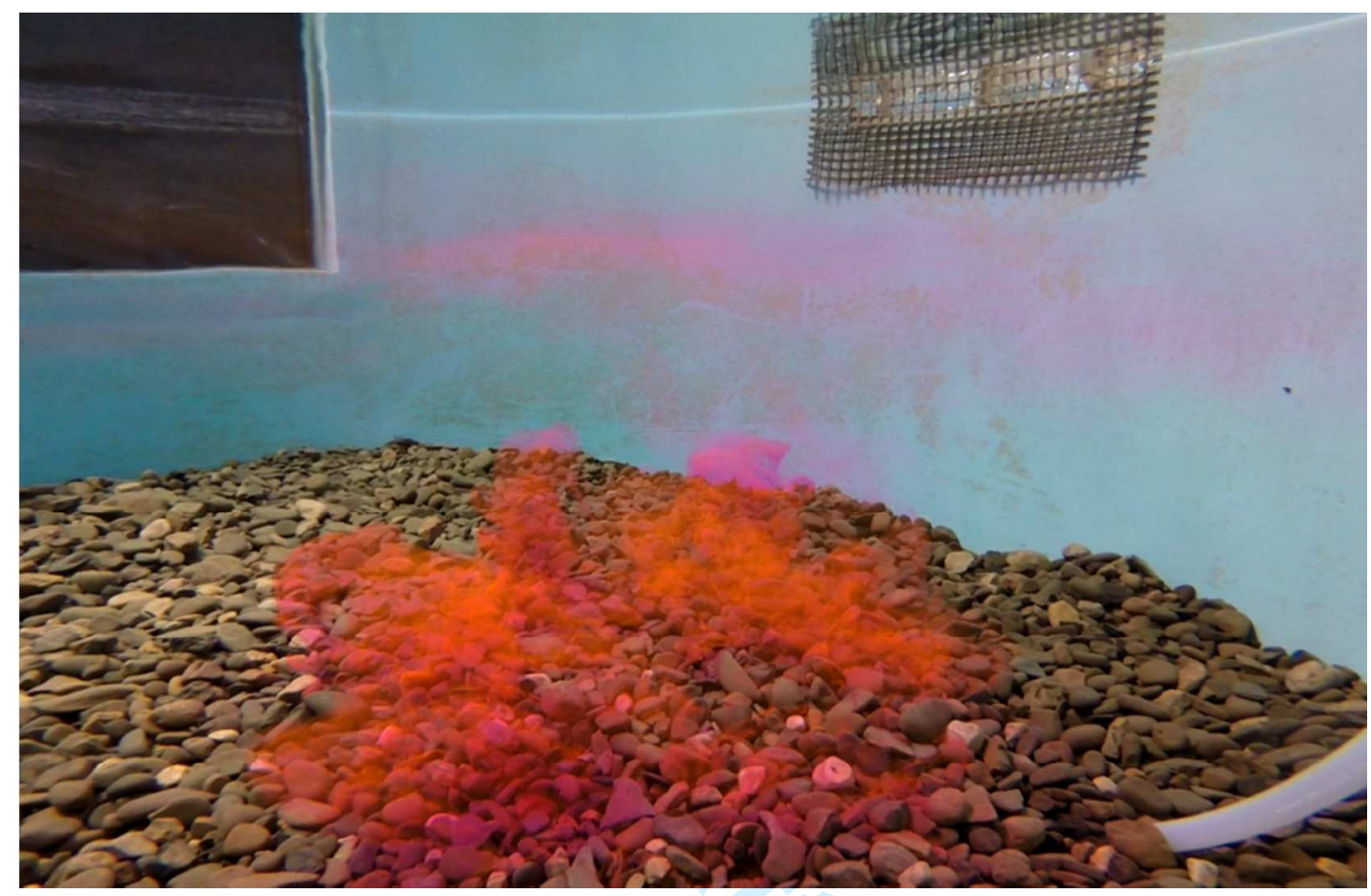

